Columbia Law School

Scholarship Archive

\title{
Preventing the Bad from Getting Worse: The End of the World (Trade Organization) As We Know It?
}

\author{
Bernard Hoekman \\ European University Institute, Robert Schuman Centre for Advanced Studies (RSCAS), \\ bernard.hoekman@eui.eu \\ Petros C. Mavroidis \\ Columbia Law School, petros.mavroidis@unine.ch
}

Follow this and additional works at: https://scholarship.law.columbia.edu/faculty_scholarship

Part of the Antitrust and Trade Regulation Commons, Dispute Resolution and Arbitration Commons, International Law Commons, and the International Trade Law Commons

\section{Recommended Citation}

Bernard Hoekman \& Petros C. Mavroidis, Preventing the Bad from Getting Worse: The End of the World (Trade Organization) As We Know It?, EUROPEAN UNIVERSITY INSTITUTE, ROBERT SCHUMAN CENTRE FOR Advanced Studies, Global Governance Programme Working Paper No. RSCAS 2020/06 (2020).

Available at: https://scholarship.law.columbia.edu/faculty_scholarship/2606

This Working Paper is brought to you for free and open access by the Faculty Publications at Scholarship Archive. It has been accepted for inclusion in Faculty Scholarship by an authorized administrator of Scholarship Archive. For more information, please contact scholarshiparchive@law.columbia.edu. 

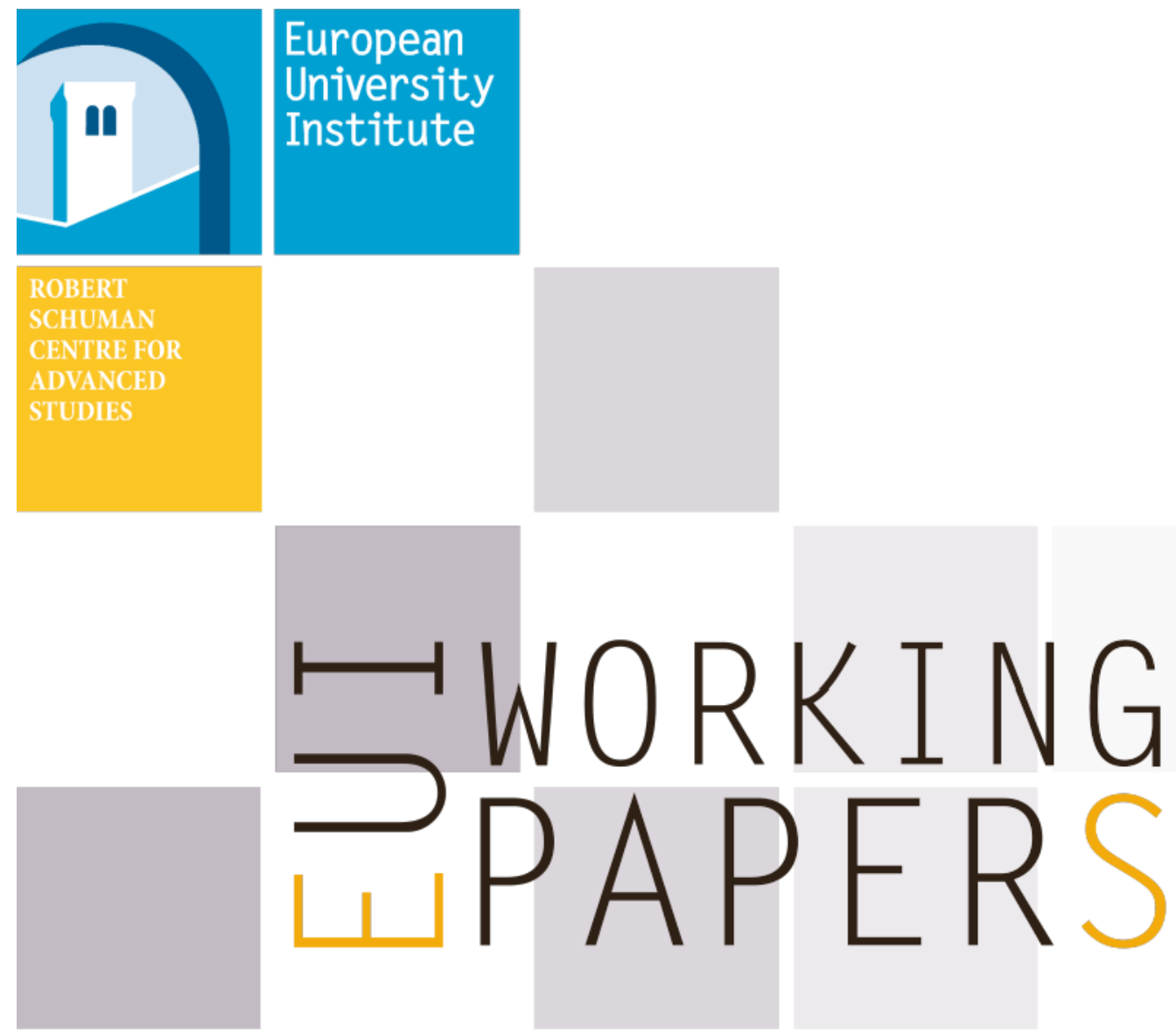

RSCAS 2020/06

Robert Schuman Centre for Advanced Studies Global Governance Programme-381

Preventing the Bad from Getting Worse: The End of the World (Trade Organization) As We Know it?

Bernard M. Hoekman and Petros C. Mavroidis 
European University Institute

Robert Schuman Centre for Advanced Studies

Global Governance Programme

Preventing the Bad from Getting Worse: The End of the World (Trade Organization) As We Know it?

Bernard M. Hoekman and Petros C. Mavroidis

EUI Working Paper RSCAS 2020/06 
This text may be downloaded only for personal research purposes. Additional reproduction for other purposes, whether in hard copies or electronically, requires the consent of the author(s), editor(s). If cited or quoted, reference should be made to the full name of the author(s), editor(s), the title, the working paper, or other series, the year and the publisher.

ISSN 1028-3625

(c) Bernard M. Hoekman and Petros C. Mavroidis, 2020

Printed in Italy, January 2020

European University Institute

Badia Fiesolana

I - 50014 San Domenico di Fiesole (FI)

Italy

www.eui.eu/RSCAS/Publications/

www.eui.eu

cadmus.eui.eu 


\section{Robert Schuman Centre for Advanced Studies}

The Robert Schuman Centre for Advanced Studies, created in 1992 and currently directed by Professor Brigid Laffan, aims to develop inter-disciplinary and comparative research on the major issues facing the process of European integration, European societies and Europe's place in $21^{\text {st }}$ century global politics.

The Centre is home to a large post-doctoral programme and hosts major research programmes, projects and data sets, in addition to a range of working groups and ad hoc initiatives. The research agenda is organised around a set of core themes and is continuously evolving, reflecting the changing agenda of European integration, the expanding membership of the European Union, developments in Europe's neighbourhood and the wider world.

For more information: http://eui.eu/rscas

The EUI and the RSCAS are not responsible for the opinion expressed by the author(s).

\section{The Global Governance Programme}

The Global Governance Programme is one of the flagship programmes of the Robert Schuman Centre. It is a community of outstanding professors and scholars that produces high quality research and engages with the world of practice through policy dialogue. Established and early-career scholars work on issues of global governance within and beyond academia, focusing on four broad and interdisciplinary areas: Global Economics, Europe in the World, Cultural Pluralism and Global Citizenship.

The Programme also aims to contribute to the fostering of present and future generations of policy and decision makers through its executive training programme: the Academy of Global Governance, where theory and 'real world' experience meet and where leading academics, top-level officials, heads of international organisations and senior executives discuss on topical issues relating to global governance.

For more information: http://globalgovernanceprogramme.eui.eu

The European University Institute and the Robert Schuman Centre are not responsible for the opinions expressed by the author(s). 


\begin{abstract}
Recent survey evidence and proposals made in long-running negotiations to improve WTO dispute settlement procedures illustrate that many stakeholders believe the system needs improvement. The Appellate Body crisis could have been avoided but for the use of consensus as WTO working practice. Resolving the crisis should prove possible because the matter mostly concerns a small number of more powerful WTO members. We make several proposals to revitalize the WTO appellate function but argue that unless the WTO becomes a locus for new rulemaking, re-establishing the appellate function will not prevent a steady decline in the salience of the organization. A key challenge is that plurilateral cooperation go beyond a focus on good regulatory practices and coordination failures and address sources of major trade spillovers. Doing so will depend on resolving the dispute settlement conflict given the need for new plurilateral agreements to be enforceable.
\end{abstract}

\title{
Keywords
}

WTO; Appellate Body; dispute settlement; trade agreements; decision-making.

JEL Classification: F15; K40 


\section{Introduction*}

The WTO dispute settlement system - compulsory third-party adjudication - long held to be the crown jewel of the multilateral trading system, is in crisis, potentially endangering the future of the organization. Starting in 2017, alarm bells began ringing regarding the implications of the dwindling number of Appellate Body (AB) members, the result of the United States blocking new appointments as the terms of sitting members expired. ${ }^{1}$ At the time of writing, the number of $\mathrm{AB}$ members stands at one, making the appeals function of the WTO dysfunctional (at least three AB members are needed to consider an appeal of a panel report). Worse, there is now certainty that $\mathrm{AB}$ members that have stepped down will not accept to continue to serve in divisions hearing cases. ${ }^{2}$ As a result, there is no longer a multilateral forum to hear new appeals. Some WTO Members, notably the European Union (EU), are seeking to put in place alternative mechanisms to permit participants to appeal panel reports. In parallel, efforts will continue to build on the results of the consultations by Ambassador David Walker on addressing the concerns expressed by the United States, even though they do not lend to optimism so far. $^{3}$

While the end of the AB does not spell the end of the WTO (in the sense that, at best, it would touch upon one of its functions only), many WTO Members have made clear they think the demise of the AB is a serious problem. The main fear is that, without the AB, the WTO dispute settlement system will lose much of its predictability and may eventually collapse. This, in turn, has potentially major consequences for future rule-making efforts in the WTO, as the value of negotiated outcomes depends on the ability of signatories to enforce them. In this latter view, the different pillars of the WTO are interdependent, and a collapse of its adjudicatory function risks generating a domino effect. ${ }^{4}$

For the moment, panels continue to be established, suggesting that WTO Members retain confidence in the dispute settlement system even if this does not include a functioning $\mathrm{AB}$. This positive aspect comes with a heavy touch of grey: there is uncertainty regarding the outcome of new disputes submitted to panels. The WTO has taken no official position regarding the question whether the correct interpretation of Article 16.4 of the $\mathrm{DSU}^{5}$ entails that an appeal to a nonexistent $\mathrm{AB}$ is possible or not. ${ }^{6}$

* We are grateful to Rodd Izadnia, Mark Koulen, Robert McDougal, Ulli Petersmann and Robert Wolfe for helpful discussions and suggestions. This paper is part of a Bertelsmann Stiftung supported research project on WTO reform.

1 See for example the IELP blog at https://worldtradelaw.typepad.com/. The first US refusal to join the consensus was in 2016, when it opposed re-appointment of Sheung Wa, a Korean national, who was forced to resign. The US did not oppose the appointment of his successor, Hyung Chong Kim, or oppose the appointment of Mrs. Hong, a Chinese national, who succeeded Mrs. Zhang, the first ever Chinese member of the AB. Since then the US has opposed every (re-)appointment.

2 Thomas Graham, the US member of the AB who stepped down on December 11, 2019, joined a US law firm, and thus, became ipso facto ineligible to adjudicate disputes, https://insidetrade.com/trade/former-appellate-body-chair-grahamjoins-cassidy-levy-kent.

3 See WTO JOB/GC/222, October 15, 2019.

4 Although retracted within a few days on agreement on a trimmed budget that significantly reduced the expenses of the $\mathrm{AB}$, the refusal of US delegation in November 2019 to agree to a "business as usual" WTO budget for 2020 illustrates that the boundary between the AB crisis and the operation of the WTO more broadly is far from watertight. The US argued that the WTO budget should be reduced given the demise of the AB should lead to re-configuration of the expected expenditure. See https://www.bloomberg.com/news/articles/2019-11-12/u-s-is-said-to-raise-prospect-of-blocking-passage-of-wtobudget.

5 DSU stands for Dispute Settlement Understanding, the WTO Agreement detailing the process for adjudication before the competent WTO bodies. The DSU is overseen by the Dispute Settlement Body (DSB), a council in which all WTO members participate that deals with the day-to-day operations of dispute settlement at the WTO.

6 Article 16.4 reads: "Within 60 days after the date of circulation of a panel report to the Members, the report shall be adopted at a DSB meeting unless a party to the dispute formally notifies the DSB of its decision to appeal or the DSB decides by consensus not to adopt the report. If a party has notified its decision to appeal, the report by the panel shall not be considered 
If not, panel reports will be the final word, and this would signal the effective return to the GATT days, albeit with negative consensus (since defendants will be in no position to block adoption as per Article 16.4 of DSU) when it comes to adoption of reports. If appeal ("into the void") is possible, issued panel reports will have no legal value at all. ${ }^{7}$ Some WTO members are seeking to self-insure against this risk by developing alternative appeal mechanisms. A prominent example is an EU-led initiative to have panel reports heard by an ad hoc appellate process. ${ }^{8}$ Such initiatives constitute partial patch-up solutions at best. They risk creating a multi-tier system across WTO members, as some will participate in an appellate process, and some will not. This is unlikely to result in an internally coherent jurisprudence, the raison d'être of any appellate process.

The $\mathrm{AB}$ crisis is usually presented as the United States against the world. This is surely the case when it comes to tactics. ${ }^{9}$ Absent US resistance to (re)appoint members of the $\mathrm{AB}$, the $\mathrm{AB}$ would still be in place and functioning. The situation, nevertheless, is more complicated. Even though other WTO members did not support the US method to express dissatisfaction with the workings of the $\mathrm{AB},{ }^{10}$ many of the issues raised by the United States are not new. ${ }^{11}$ As we note below, some were first tabled almost 20 years ago in the long-running and unsuccessful DSU Review. Over the years, many suggestions to improve the operation of WTO dispute settlement were made by WTO members and outside experts, to little effect. The proximate reason is WTO working practice, notably consensus-based decision-making. Consensus precluded adoption of proposals made over the years by many WTO Members on DSU reform. Consensus also permitted the United States to block new AB appointments.

The status quo bias resulting from the (ab)use of consensus has arguably been a factor leading many WTO members to conclude preferential trade agreements (PTAs). While consensus has long been recognized as a factor impeding decision-making, ${ }^{12}$ it should not be regarded as the central cause of the

for adoption by the DSB until after completion of the appeal. This adoption procedure is without prejudice to the right of Members to express their views on a panel report." The question is whether the part of this provision following the term "DSB meeting" still has a raison d'être with the AB reduced to one member, and thus, unable to function. If not, then all panel reports would be adopted automatically, unless a consensus against their adoption emerged. Thus, losing parties could not appeal to an inexistent $\mathrm{AB}$ in order to avoid implementing adverse panel findings. Only future practice will respond authoritatively to this question, which, for now, is unresolved. Ironically, the first test case for this involves the US. On December 18, 2019, the US lodged an appeal "into the void" against an Art. 21.5 compliance Panel report (DS436, US countervailing duties on certain steel products from India). In a subsequent document (WTO Doc. WT/DS436/22 of January 16, 2020), the two disputing parties clarified that they would submit an appeal only when an AB Division could be established. At the moment of writing, this date is unclear.

7 Petersmann (2019) and Pauwelyn (2019) discusses scenarios and possible paths forward for WTO dispute settlement following the demise of the $\mathrm{AB}$.

8 In January 2020, Australia, Brazil, Chile, China, Colombia, Costa Rica, Guatemala, South Korea, Mexico, New Zealand, Panama, Singapore, Switzerland and Uruguay agreed they would join the EU, Canada and Norway in participating in this initiative (https://www.reuters.com/article/us-trade-wto/eu-china-other-wto-members-agree-temporary-body-to-settledisputes-idUSKBN1ZNOWM). See https://trade.ec.europa.eu/doclib/press/index.cfm?id=2053 for a description of the envisaged mechanism.

9 While the Trump Administration precipitated the crisis, the Obama Administration was also unhappy with the AB, as have been influential US law firms and lobbyists.

10 This is clearly reflected in the proposal, supported by 120 members at the time of writing, calling for launching selection processes for the six vacancies in the Appellate Body (as of January 2020, China's Hong Zhao is the only Appellate Body member remaining). Mexico, speaking on behalf of the 120 WTO members noted that the large number of members supporting the proposal reflects a common concern that a nonoperational Appellate Body will negatively affect the workings of the overall dispute settlement system, which is against the best interest of members. Mexico stressed that WTO members have a responsibility to safeguard and preserve the $\mathrm{AB}$, the dispute settlement system, and the multilateral trading system.

11 McDougal (2018) and Payosova, Hufbauer and Schott (2018) provide excellent discussions of US concerns and options to address them.

12 See Ehlermann and Ehring (2005), Tijmes-Lhl (2009) and Wolfe (2009) on the role of consensus in WTO decision-making and bargaining. 
problem. Increasing geopolitical rivalry between the US and China, and more broadly shifts in the structure of the global economy (the rise of large emerging economies), have led to substantive disagreements between large actors that cannot be addressed through relaxing the consensus constraint. A necessary condition for resolving the dispute settlement dispute is agreement between the major trading powers.

Even if the AB dispute can be resolved, the WTO cannot serve as a forum to adjudicate disputes regarding non-WTO law. Resolving the $\mathrm{AB}$ dispute, while important, will not address the wider crisis confronting the WTO. As is, the WTO cannot serve as a forum to adjudicate disputes regarding nonWTO law. It is not a court of general jurisdiction in all matters regarding the interpretation of international law, like the International Court of Justice (ICJ). If the legislative function of the WTO continues to stall, the volume of adjudication before the WTO will suffer as well, even if - as we expect - the membership manages to overcome the $\mathrm{AB}$ crisis. A reconstituted $\mathrm{AB}$ will do little to safeguard the future relevance of WTO, if new trading rules are not negotiated.

On the rulemaking front the WTO is still breathing, but only shallowly. The main focus now is plurilateral. Plurilateral cooperation has been the name of the game for over 20 years, reflected in the many PTAs that WTO members have concluded since 1995. PTAs build on the foundations established by the WTO. We expect these foundations to endure, but the problem is that they are too limited in scope. Plurilateral agreements hold promise as a mechanism to expand the reach of multilateral rules to those WTO members who want to extend the WTO. Current plurilateral talks are a positive sign the WTO has exited the Doha coma, but they carry a heavy burden of proof in demonstrating they can result in substantive agreements. If they do not, the WTO will continue to administer past commitments made by members, but its policy relevance will inevitably erode.

There is therefore a two-fold challenge confronting the WTO: (i) to address the current conflict on the operation of the dispute settlement mechanism; and (ii) to revitalize the multilateral organization as a locus for new rulemaking. ${ }^{13}$ It is only by addressing both challenges that faith in multilateralism can be restored. As argued in previous work (Hoekman, 2014; Hoekman and Mavroidis, 2015), PTAs are no longer the outside option, they have become the default. In part, this reflects the negative experiences associated with issue-linkage strategies and veto playing in WTO deliberations. More fundamentally, it reflects the nature of the policies involved. Even if countries act in good faith and are willing to refrain from issue-linkage games, consensus on an issue may be impossible if national preferences differ substantially. The WTO will need to accommodate plurilateral cooperation if it is to "compete" with PTAs. In 2017, WTO members decided to start down this track by ignoring the consensus practice and launching plurilateral negotiations. This is a positive development. For the WTO - and WTO dispute settlement - to remain relevant, a necessary condition is that substantive, meaningful plurilateral agreements emerge that address major sources of policy spillovers. The feasibility of concluding such agreements will depend in part on effective enforcement. Thus, resolving the narrow dispute settlement crisis is necessary both to sustain the WTO 'as is' and to allow the WTO to move forward.

The remainder of the paper is organized as follows. Section 2 briefly summarizes the main findings of a recent survey of practitioners, stakeholders and WTO delegations regarding their perceptions of the $\mathrm{AB}$ and WTO dispute settlement more broadly. In Section 3, we reflect on the experience with the forum established by WTO Members to discuss the operation of the DSU. Some of the issues that led to the demise of the $\mathrm{AB}$ are longstanding. Both survey responses and the history of the DSU Review illustrate that while dispute settlement may be the crown jewel of the WTO, it has imperfections. This is neither surprising nor contested. The problem is that the WTO membership collectively has been unable - more accurately, unwilling - to make timely repairs and allowed the jewel to crack.

In Section 4, we argue that the $\mathrm{AB}$ crisis is not self-contained. The inability to agree to revise dispute settlement processes parallels the failure of the WTO members to update the substantive rules of the

13 See also Condon (2018) and McDougal (2018) in this regard. 
game. The current situation is one where the United States is no longer willing to act as a benign hegemon and OECD nations are unwilling to accept a significant degree of free riding by large emerging economies. A trend towards conditional MFN agreements seems inexorable given the types of policies that create cross-border spillovers today often are regulatory in nature, implying that cooperation must be conditional in the sense that commitments entered into will affect countries that are not members of an agreement if they cannot satisfy minimum standards agreed by a group - or do not wish to do so. Plurilateral agreements are not a panacea, but they do provide a mechanism for the larger players to address issues that are giving rise to trade tensions and/or are likely to do so in the near future (e.g., trade policy dimensions of an EU Green Deal) within a cooperative framework as opposed to unilaterally. They are also arrangements that can expand over time to include new members willing to chip in and participate.

Section 5 presents suggestions on dispute settlement reform and addressing the wider crisis confronting multilateral rulemaking. Our presumption is that negotiation under the guise of a single undertaking is not feasible - at least for the near future. Instead, policy spillovers generating geopolitical tensions will need to be addressed through plurilateral initiatives. Ideally, these will involve the major trading powers and be open to broad participation. We argue the WTO membership should facilitate the operation of clubs and seek to agree to disciplines that will support the gradual multilateralization of their output. In this context, it is important to determine what role dispute settlement should play relative to other means and mechanisms to sustain plurilateral cooperation. Section 6 concludes.

\section{WTO Dispute Settlement: Institutional Design and Organizational Procedures}

How much do WTO members and the trade community care about WTO dispute settlement? Is the United States an outlier in how it assesses WTO performance in this area? Fiorini et al. (2020) collect information that addresses these questions. A first stylized fact, noted in numerous empirical assessments of the use of WTO dispute settlement (e.g., Horn et al. 2005), is that the use of these procedures is highly skewed towards large and richer players. A similar pattern applies when the focus of attention is on participation in WTO deliberations on the AB in the 2016-19 period, during which the United States consistently blocked new appointments to the AB. These indicators of revealed preferences reveal that those who use the system more engage more in deliberations on reform and efforts to address the AB crisis. Most WTO members are bystanders.

Fiorini et al. $(2019 ; 2020)$ supplement data on the use of the DSU and participation in WTO deliberations on the AB with an on-line questionnaire of WTO delegations and other stakeholders to elicit their perceptions regarding the operation of the dispute settlement system. ${ }^{14}$ Officials from 25 WTO members ${ }^{15}$ responded to the survey, with a marked preponderance of responses originating in the largest traders, more open and richer economies. ${ }^{16} \mathrm{~A}$ commonality across the survey responses and indicators of participation in dispute settlement is that most developing countries do not engage. Most WTO members asked to complete the survey did not do so. ${ }^{17}$ Bearing in mind that responses are skewed

14 Fiorini et al. (2019) list all the questions asked, and provide descriptive information on responses received. In addition to WTO delegations, the survey was sent to legal practitioners, the International Chamber of Commerce (ICC), the Pacific Economic Cooperation Council (PECC), and the WEF (World Economic Forum), in all cases with a request to pass on the survey to others engaged in or concerned with WTO dispute settlement.

15 In what follows for purposes of characterizing responses to the survey total WTO membership is defined as comprising 136, i.e., we count the $28 \mathrm{EU}$ member states as one.

16 Survey response rates are often low, but in this case, the low level of response is rather striking given that the questionnaire targeted governments and professionals directly concerned with the imminent demise of the $\mathrm{AB}$, a high-profile issue in the Geneva trade community at the time the survey was run (mid 2019).

17 No government officials from China, Japan and the United States responded. Moreover, no officials from large emerging economies such as Mexico, Russia, Indonesia, and Argentina that are active in the DSU and DSB debates participated in the survey 
to those with sufficient interest to respond, we draw two main conclusions from the survey responses. First, respondents are generally supportive of the design of WTO dispute settlement, and the basic features of the DSU are regarded as desirable. Second, some respondents expressed concerns with the way the $\mathrm{AB}$ has exercised discretion in pursuing its mandate.

Were we to characterize the design of dispute settlement (the DSU) as the legal 'institution', and the $\mathrm{AB}$ as a key 'organization' entrusted with its administration, it is the organizational aspect of dispute settlement, and more specifically its practice, that dominated the concerns expressed by the United States, not the design of the institution as such. ${ }^{18}$ As we discuss in Hoekman and Mavroidis (2020), it is noteworthy that the institutional design aspects of DSU were heavily negotiated during the Uruguay Round, whereas its organizational features were given little attention. Article 17 DSU leaves the elaboration of $\mathrm{AB}$ Working Procedures to the $\mathrm{AB}$. This delegation is no longer accepted by the United States.

\subsection{Support for the basic institutional design}

Most respondents agree on the objective function of dispute settlement at the WTO, and strongly support the introduction of compulsory third-party adjudication, as negotiated in the Uruguay round. Most regard the $\mathrm{AB}$, as such, and WTO dispute settlement in more general terms, to be of critical importance to the functioning of the world trading system. This is quite rational. There are two foundational reasons why enforcement is necessary for the WTO to function. First, governments may have incentives to renege on negotiated commitments. Even though the distinction (and ensuing classification) between good- and bad-faith disputes remain an unsolvable conundrum in contract theory, political economy forces might tilt the balance towards less defensible interpretations of agreed obligations and provoke a retaliatory reaction by other parties and unravelling of cooperation. Enforcement through peaceful means is a mechanism to avoid such an outcome. Second, enforcement is necessary because WTO agreements are incomplete contracts. It is impossible to negotiate every policy affecting trade, as potentially any policy can affect trade. Two options exist to address a need to 'complete' the contract: (re-) negotiation and adjudication. Re-negotiation has an advantage over adjudication in that it binds all WTO members. The downside is that it is very onerous, given the large number of WTO members (164), their heterogeneity, and the fact that decisions are adopted by consensus. Adjudication, on the other hand, binds only the parties to a particular dispute, although the de facto precedential character of $\mathrm{AB}$ rulings is a mitigating factor. The upside is that adjudication involves only the volition of the complainant. As such, it may be perceived as the only feasible option to complete the contract and allow it to produce its intended results. ${ }^{19}$ Assuming precedent is observed, adjudication becomes quite attractive as means to do so. ${ }^{20}$

\subsection{Polarization on organization and performance}

Although there is widespread agreement in favour of keeping a two-instance compulsory third-party adjudication in place, a substantial share of survey respondents indicate dispute settlement is not doing

18 That said, in the 2018 USTR Trade Agenda, an official strategy document, the US government seems to detract from negative consensus. See: https://ustr.gov/sites/default/files/files/Press/Reports/2018/AR/2018\%20Annual\%20Report\%20FINAL.PDF),

19 This arguably is too narrow a view given that other forms of dispute resolution are available to WTO Members, such as raising specific trade concerns in Committees. Bolstering the use of such alternative mechanisms to defuse conflicts and resolve concerns is arguably one important dimension of WTO reform (Wolfe, 2020a).

20 The US has, of course, voiced strong criticism against the presumption of binding precedents in WTO case law, a matter on which the DSU is clear. 
what it should be doing, and/or does not consistently deliver high quality output. ${ }^{21}$ Some $55 \%$ of all respondents believe that panel reports are sometimes biased. This number increases for Geneva based officials who are involved in dispute settlement, 70\% of whom perceive panel reports are sometimes biased. Many business respondents and legal practitioners believe that the $\mathrm{AB}$ has not provided coherent case law (40\% and 50\%, respectively). Almost one-third (30\%) of officials in capitals dealing with dispute settlement agree the $\mathrm{AB}$ has not provided coherent case law. More than three-quarters of delegation officials based in Geneva directly involved in dispute settlement who responded to the survey report that the $\mathrm{AB}$ has at times acted inconsistently with the DSU.

A sizeable share of survey respondents regard case law as sometimes incoherent and have doubts regarding absence of bias in reports. Of specific relevance to US concerns, $42 \%$ of respondents agree the AB has gone beyond its mandate, violating Article 3.2 of the DSU not to undo the balance of rights and obligations negotiated by the membership. The shares are higher for government officials based in Geneva involved in dispute settlement (50\%) and practitioners in law firms $(60 \%)$. We do not know what the basis for these views are. One potential factor may be perceptions of undue influence of the Secretariat in drafting reports. ${ }^{22}$ Also of note, is that survey respondents from developing countries were more inclined to agree that WTO dispute settlement is too expensive, that bilateral consultations are preferable to submission of disputes to the WTO, and that the introduction of monetary damages would be desirable in making the system more relevant to them. There are also clear splits across the rich-poor divide regarding whether business is well informed on foreign market access barriers (in rich countries, the response is an overwhelming "yes", whereas in poor countries, the opposite).

Our takeaways from patterns of use of the DSU, participation in the DSB, and survey responses are that: (i) the system is primarily of interest to large and richer players; (ii) there is near universal agreement on the appropriateness of the institutional framework; (iii) many insiders agree with some of the concerns raised by the United States regarding the operation of the system; and (iv) specific design features may reduce the salience of the system for low-income countries. Some of these dimensions figured in the DSU Review, to which we turn next.

\section{The DSU Review: Improving Organizational Performance}

Much of the commentary on the $\mathrm{AB}$ crisis gives an impression the conflict is a recent one and that it is part of the more general attack by the Trump Administration on multilateral institutions. Unfortunately, the crisis is not totally idiosyncratic, although the very confrontational stance taken by the US Administration is unprecedented. Basic elements of US scepticism about the DSU were already expressed over two decades ago. In 1995, worried about the powers that the newly formed AB might exert, Senator Robert Dole suggested a "three strikes" rule: a US review panel would evaluate whether the $\mathrm{AB}$ had overstepped its mandate, and if it happened three times, it would recommend a withdrawal from the WTO. ${ }^{23}$ In recognition of such concerns, and because the DSU was a major innovation, Uruguay Round negotiators built in a formal review of the operation of the dispute settlement system. The DSU Review was to commence within four years of the entry into force of the WTO. It accordingly was initiated in 1998 and extended in 2001 in parallel with the launch of the Doha Round, with Ministers establishing a mandate to use the work done up to that point as a basis for negotiations to improve and clarify the DSU. ${ }^{24}$

21 Specific numbers in this and the following paragraph are from Fiorini et al. (2019) which reports much more detailed results.

22 https://twitter.com/bbaschuk/status/1201923246930759680.

23 https://www.joc.com/dole-presses-measure-wto-review-panel-senator-seeks-counter-charges-hes-softtrade_19951116.html.

24 The DSU Review was not part of the Doha Development Agenda single undertaking. It was conceived as a stand-alone exercise. See WTO Ministerial Declaration, Fourth Session of the Ministerial Conference, WT/MIN(01)/DEC/1, para. 30. 


\subsection{What was the Review meant to accomplish?}

The Review was meant to be a forum for WTO members to address problems with the implementation of the DSU and to improve it, if warranted. Envisaged to conclude by 2004, the process never led to any agreement. The Review was tasked with generating suggestions to "improve and clarify" the DSU. It was extended beyond the original deadline of 2004, and formally remains ongoing. In principle, therefore, it provided an institutional mechanism through which matters underlying the $\mathrm{AB}$ crisis could have been addressed. Members, consequently, did not have to establish a new group or committee to deal with the $\mathrm{AB}$ crisis, since all of them could participate in the Review.

Although pressure for tweaking the DSU was not strong in the early 2000s, given a general sense that it was working well, the Review generated many proposals to improve the operation of the DSU. ${ }^{25}$ As is the case for other dimensions of dispute settlement, participation in the Review has tended to be limited to the large players, but many developing countries also put forward proposals. Of interest for the topic of this paper is the extent to which the Review included key criticisms voiced by the United States, and whether similar issues were raised by other members.

\subsection{Issues discussed in the DSU Review}

A June 2019 report by Ambassador Coly Seck (Senegal), the latest Chairperson of the group charged with review and updating of the DSU, provided an update on the state of play after 20 years of discussion. ${ }^{26}$ This report is at the same time an admission that the process was deadlocked and a succinct description of what has happened so far. We say "so far" since, technically, the Review is still running.

Proposals on the table at the time when the report of Ambassador Seck was issued had dealt with the following subjects: (i) mutually agreed solutions; (ii) third-party rights; (iii) strictly confidential information; (iv) sequencing; (v) post-retaliation; (vi) transparency and amicus curiae briefs; (vii) timeframes; (viii) remand; (ix) panel composition; (x) effective compliance; (xi) developing country interests, and (xii) flexibility and Member control.

Although some major issues like remand were on the agenda, many others were not. These included fundamental design issues such as the nature of available remedies, liability rules (caps), and operational issues such as the use of panellists not included in national rosters and whether the WTO Secretariat should have discretion in adding panellists to the approved roster. WTO members had different views on the salience of the various subjects included on the DSU Review negotiating agenda. Since the focus in this paper is to examine the AB crisis within the larger WTO crisis, and since it is the United States that created the former, we divide the subjects addressed in the Review into those raised by the US delegation and those raised by the rest of the membership. The United States was isolated in some, but not all the concerns it raised. ${ }^{27}$

\subsubsection{Issues raised by the United States}

Issues raised by US reflected its view that the AB is an agent of the WTO membership (the principals), and, as a result, has no business going beyond what the principals tasked it with through the DSU. In

25 McDougall (2018) provides a comprehensive discussion of the DSU Review.

26 WTO Doc. TN/DS/31. These include issues such as the remedies available (e.g., Bronckers and van den Broek, 2005; Limao and Saggi, 2008; Mercurio, 2008) and the feasibility-cum-incentives to use of dispute settlement procedures by and against low-income countries (e.g., Bown and Hoekman, 2008; Nordström and Shaffer, 2008).

27 We abstract from the question whether the US decision that led to the AB crisis was the consequence of its disillusion with the Review process, or the outcome of a separate process aiming to insulate the current US administration from whatever international obligations had been tying its hands. What we are interested in is to determine what issues were raised by the US in the DSU Review. 
practice, the US argued, it had done so. The agency nature of the $A B$ is, of course, unambiguous. The wording of Article 3.2 of DSU leaves no doubt in this respect:

The dispute settlement system of the WTO is a central element in providing security and predictability to the multilateral trading system. The Members recognize that it serves to preserve the rights and obligations of Members under the covered agreements, and to clarify the existing provisions of those agreements in accordance with customary rules of interpretation of public international law. Recommendations and rulings of the DSB cannot add to or diminish the rights and obligations provided in the covered agreements. (emphasis added)

It is the alleged violation of the institutional mandate that the current critique of the $\mathrm{AB}$ by the United States aims to redress. It was raised in the Review under agenda items that came to be called "Flexibility and Member control" and "Additional guidance for WTO adjudicative bodies." Discussions under this heading did not explicitly focus on potential re-engineering of Article 3.2 of DSU, but instead revolved around increasing political (member) control and oversight of the AB.

A 2002 proposal put forward by the US and Chile 28 on "improving flexibility and member control in WTO dispute settlement" was aimed in large part to address the US concern regarding some AB rulings on safeguards and subsidies. $A B$ practice in the realm of safeguards had made recourse to this instrument a quasi-impossibility, as discussed comprehensively by Sykes (2003). Moreover, the AB finding that the US FSC (Foreign Sales Corporation) legislation, which exempted US exporters from US taxes, was an export subsidy, generated significant ire in the United States. It is unlikely that the Chile-US proposal was motivated by concerns about the $\mathrm{AB}$ case law on antidumping (zeroing), since cases on this matter before 2002 concerned the use of zeroing by the EU. Whatever the case, the proposal called for removal of specific panel or $\mathrm{AB}$ findings by mutual agreement of the disputing parties; permitting for the partial adoption of DS reports, and "some form of additional guidance to WTO adjudicative bodies" (Hauser and Zimmerman, 2003). Many WTO members rejected this on the basis it would benefit the large players in the WTO. The same was true for a complementary proposal by the US to make the dispute settlement process more transparent and open to the public.

\subsubsection{Issues raised by other members}

Other proposals made in the DSU Review might have helped prevent the AB crisis if they had been adopted. An example is an EU suggestion to establish a permanent body of panellists (i.e., a true first instance court). This could have reduced the need for appeal by improving the quality and consistency of reports, and reducing the discretion of (reliance on) the WTO Secretariat in the selection of panellists and drafting of reports. ${ }^{29}$ The EU subsequently withdrew this proposal due to lack of support, reflecting concerns that members of a permanent panel body might be 'too' independent (Hauser and Zimmerman, 2003).

Proposals by developing countries addressed issues that the Fiorini et al. $(2019 ; 2020)$ survey suggests continue to be of concern for lower-income countries. One proposal was to introduce retroactive remedies, including payment of legal costs by the losing party, in instances where a WTO member does not implement a ruling. ${ }^{30}$ Another was to permit collective retaliation, many WTO members have long resisted on the basis that the objective is not to punish but to maintain a balance of rights and obligations (the reciprocal bargain). A practical problem with collective retaliation is that it

28 WTO Doc. TN/DS/W/28 of December 23, 2002.

29 Working practice is that the WTO secretariat proposes panelists and the Director General decides in instances where the parties cannot agree to selection of panelists.

30 Historically, developing countries have favored the introduction of rules that would allow for claims for monetary damages to be paid to them in instances where illegal measures are imposed against them by industrialized nations. Not surprisingly, GATT contracting parties always rejected this. 'Money damages, said the developed countries, were simply outside the realm of the possible. In effect, they were saying, GATT was never meant to be taken seriously' (Hudec, 2002b). 
implies a direct intrusion in sovereignty- the WTO would be requiring its members to raise tariffs (Pauwelyn, 2005). A more fundamental problem is that it is not incentive compatible. Developed countries might find it quite easy to undo a coalition of developing countries by offering tailor-made preferences to some. Trade history offers only one instance of a challenge against preferential schemes, even though discriminatory practices abound. The fear of losing out on some, even if imperfect gifts, can be a powerful incentive for beneficiaries to "bite the bullet". It is not very surprising therefore that developing countries withdrew their proposals on remedies. The majority of those proposing collective retaliation eventually joined other groups and supported proposals that did not address the question of retaliation.

It is fair to conclude that the WTO membership did not see eye to eye on the focus of the DSU renegotiation. This was in and of itself a very important hurdle for the membership to overcome, as failure to agree on at least prioritization of issues to negotiate led to the establishment of a long, unmanageable list. Another problematic feature of the DSU Review was that the agenda included matters where meaningful outcomes were unlikely to emerge. Examples include questions about effective compliance and developing countries' interests. Compliance can never be effective unless one addresses the asymmetric bargaining power of institutional players, an issue many members did not want to address. Past practice must have persuaded the membership that developing countries' concerns were adequately addressed through introduction of longer transitional periods, and/or institutions of dubious effectiveness (such as provisions requesting the taking into account of developing countries' interests, which usually have been implemented as procedural rather than substantive requirements). Instead of focusing on the low-hanging fruits and crystalize into law the emerging agreement, negotiators embarked on an open-ended discussion where nothing was agreed until everything had been agreed.

Some of the issues raised by the United States during 2018-19, e.g., the continued application of Rule 15 , or the distinction between facts and law could and should have appeared on the agenda of the DSU Review but did not. ${ }^{31}$ The rigidity of WTO working practices (consensus) precluded the Review from playing the role intended by the framers of the WTO treaty. While the counterfactual cannot be determined, it seems reasonable to assume that at least some, and perhaps many, US concerns could have been addressed. A necessary condition for this would have been greater willingness to accept proposals on which there was broad agreement and flexibility in agenda setting. An insistence on making the dispute settlement negotiations a package deal (a mini 'single undertaking') resulted in no agreement on anything. Combined with rigid insistence to stick to an agenda established in the early 2000s essentially made the DSU Review an exercise in futility. Worse, as discussions dragged on for years, the process came to be regarded as one that could not be used to address the increasingly urgent disputes about dispute settlement.

\subsection{Paying the price of an inflexible approach}

Although the need for consensus impeded a resolution on the matters raised, the organization of discussions did not help either. Participants opted for a "Christmas tree"-type of approach, where all and sundry would table their wish list, and discussions would proceed on that basis. It is not hard to imagine alternative approaches with greater prospects of success. WTO members could for example have decided first on what practice has revealed to be missing from current rules or proceeded based on

31 Rule 15 appears in the Working Procedures of the $\mathrm{AB}$. It allows for members who have been appointed in an $\mathrm{AB}$ division to adjudicate a dispute, to continue their work until completion of the proceedings, even of their mandate has in the meantime expired. The United States has cast doubt on the legitimacy of this practice, since in its view, it has been abused. $\mathrm{The} \mathrm{AB}$, on the other hand, is not a trier of facts, and should confine itself to review of legal issues. The US critique in this respect is that the $\mathrm{AB}$, by conflating issues of law and facts, has on occasion ended up discussing factual issues (such as understanding of domestic law, which is, as per WTO standing jurisprudence, a factual issue), over which it has no jurisdiction. 
grievances regarding practice. It appears there was no attempt to establish criteria for including items in the agenda.

Once items had been included in the long agenda, the approach taken towards the negotiations was to pursue "sequential focused work", with the DSB in Special Session (i.e. in negotiating mode) discussing one issue at a time. ${ }^{32} \mathrm{~A}$ reason for this was to reduce the scope for WTO members to engage in issue-linkage attempts. ${ }^{33}$ Furthermore, the DSU Review started as an attempt to collect the lowhanging fruits, where de facto agreement had emerged through consistent practice. A prominent illustration is the 'sequencing issue'. This pertained to the question whether requests for authorization to retaliate must await the definitive outcome of a compliance panel. The short answer is yes. Request for retaliation cannot, as a matter of (legal) logic precede a finding of lack of compliance. Otherwise, the risk is that a member could be authorized to retaliate against practices that eventually are found to be WTO-compliant. ${ }^{34}$ When this type of 'harvesting' proved more difficult than anticipated, the Christmas tree became unmanageable, and none of the items appearing on the agenda was negotiated to conclusion. The most contentious issues, including those the US delegation had been voicing inside and outside the WTO, were never discussed in comprehensive manner, let alone with a view to conclude an agreement.

Subsequent to the initiation of the AB crisis in 2017, some WTO members expressed the view that several initial negotiating agenda items were no longer relevant, and that other, more urgent matters, should be addressed on priority basis. The crisis should have provided the membership with sufficient incentive to change course and discuss whatever was necessary to redress the downfall of the AB. The inability to respond flexibly to changed circumstances and priorities is an illustration of the inefficiencies associated with the WTO working practice based on consensus. Many WTO members tend to argue that WTO bodies must stick to mandates given to them by the Ministerial Conference (Hoekman, 2019). While this may reflect a fear of being blind-sided and/or steam-rolled by large players, the result is counter-productive rigidity. The experience of the DSU Review illustrates the opportunity cost of WTO working practice.

\subsection{An attempt to save the day through a separate process}

The specific issues raised by the United States starting in 2017 regarding the functioning of the AB eventually became the focus of a separate process launched by the General Council in December 2018. Ambassador David Walker (New Zealand) was appointed as "facilitator", a WTO term denoting an individual is entrusted with the task of organizing a narrowly defined specific negotiation/task. Ambassador Walker's mandate included issues that had appeared in the DSU Review and arguably should have been addressed well before the crisis erupted. Several of the issues included but not negotiated in the DSU Review, and inserted in the mandate of Ambassador Walker, map into concerns raised by the United States in the DSB as justification for its decision not to join a consensus to appoint new members of the $\mathrm{AB}$. These concerns included the fact that the $\mathrm{AB}$ often did not issue findings within the timeframe specified in the DSU (item vii, in the list of items in Ambassador Seck's report cited above) and that the $\mathrm{AB}$ sometimes exceeded its mandate by filling gaps or ruling on matters where the

32 In response to some participants wanting to make more rapid progress, the work on the last four issues on the DSU agenda (panel composition; effective compliance; developing country interests, and flexibility and Member control. was pursued through separate, parallel meetings (WTO, 2019, p. 3).

33

"In the absence of a collective political will to promptly complete the DSU negotiations, proponents have in some cases sought to establish linkages across unrelated issues. While such approaches are common in multilateral trade negotiations, this has also limited the ability for the various proposals to be considered on the basis of their individual merits." (WTO, 2019, para 1.11)

34 Following the initial EC-Bananas III litigation, where the opposite had been the case, decision to authorize countermeasures had followed findings by compliance panels to the effect that the findings of the original panel had not been implemented. The only exception to this rule is the December 2019 report on the Airbus-Boeing saga (DS316). 
WTO rules were ambiguous (item xii). Providing the $\mathrm{AB}$ with the ability to remand cases back to panels (item viii) is also relevant in this regard, as this would help ensure that the $A B$ does not perceive a need to step in for panels.

\subsection{A "half-baked" AB and a dysfunctional legislative process did not help}

Over time, absence of $\mathrm{AB}$ restraint on zeroing led to rising tensions with the United States - as already foreseen by observers such as Barfield (2001). A necessary condition for resolving such tensions was also well understood: a functioning political decision-making mechanism. In an assessment of the DSU Review, Hauser and Zimmerman (2003) noted that rulings by adjudicative bodies on matters where negotiators were unable to agree on clear treaty text inevitably would create political tensions that in turn would be difficult to correct because of the consensus working practice. A stubborn, or let us say not nuanced enough $\mathrm{AB}$, was operating unfettered by meaningful constraints.

The organizational aspects of adjudication had not been discussed seriously during the DSU negotiation. Vandenbossche (2006), and Hoekman and Mavroidis (2020), drawing on the negotiating record, provide ample evidence to the effect that not much thinking went into the organizational aspects of the $\mathrm{AB}$. A natural consequence was that the primary legislation was quite rudimentary. The $\mathrm{AB}$ was left to determine detailed working procedures for itself. This is where Rule 15 was decided, which became a flagship of discontent for the US delegation at least. One can only speculate what the situation might have been had such working procedures been clarified and agreed by the principals in the DSU Review, the mechanism foreseen by Uruguay Round negotiators to address such matters, as opposed to de facto delegation to the agent (the $\mathrm{AB}$ ) on how to regulate its operations.

Similarly, the DSU Review shied away from asking whether adjudication before the WTO would eventually pay the price (and if so, what?) in case the WTO legislative function would continue to underperform. In short, no medium-run strategic thinking went into the DSU Review at all, and the "thornier" of issues plaguing adjudication at the WTO were not discussed in any depth. Informal dialogue orchestrated by the Secretariat to complement the DSU Review also led nowhere, in part because it was explicitly limited to matters not tabled in the Review, for which there was no mandate to negotiate. As a result, these informal dialogues were limited to identifying potential efficiency gains in dispute settlement process. ${ }^{35}$ The consultative process undertaken by the Chair of the DSB, Ambassador David Walker in 2019 , proved to be too little too late, as by that time the key protagonists were deeply entrenched in their positions. These consultations were forced to address the relatively insignificant procedural issues raised by the United States, such as timeframes and Rule 15, diverting attention from the core issues falling under the broad heading of "WTO Member control" in the DSU Review discussions. Worse, the membership could not reach agreement on the minor issues either.

In short, observed DSU deficiencies were not addressed through legislative interventions informed by deliberations in the DSU Review. This is the heart of the issue and arguably constitutes a major threat to the continuing policy relevance of the WTO. In what follows, we highlight the impact of the asymmetric performance of the WTO's legislative and adjudicatory functions. ${ }^{36}$

\section{The AB Fight: A Crisis in a Wider Crisis}

Pause for a moment. Assume that, by magic wand, the Trump Administration changes its attitude, and agrees to new appointments to the $\mathrm{AB}$. Will the problems disappear simply because a reconstituted $\mathrm{AB}$

\footnotetext{
35 This process was launched in 2010 and engaged with WTO Members, panelists, trade law practitioners and Secretariat staff involved in WTO dispute settlement. See "Secretariat's informal consultations concerning the panel process" at https://www.wto.org/english/tratop_e/dispu_e/informal_consultations_e.htm.

36 Of course, at the time of writing the performance of both functions has converged: both are in trouble.
} 
is back in place? Even if matters such as Rule 15 are addressed, the distinction between facts and law is clarified and a resolution is found to concerns regarding the $\mathrm{AB}$ overstepping of its mandate, we are left with the fact that new trade agreements are being routinely negotiated outside the confines of the WTO, leading enforcement to migrate elsewhere. Is the $\mathrm{AB}$ crisis simply a case of missing judges or should it be viewed as symptom of a wider crisis hitting multilateralism, even if the causes for the latter are distinct?

In what follows, we argue against the commonly held view that the $\mathrm{AB}$ crisis would ipso facto be over, if the United States were to change its mind and accept new AB appointments. This view ignores both the perceptions of many insiders that the operation of the dispute settlement system needs to be improved, as well as, crucially, the broader challenges confronting cooperation in the WTO. The increasing shift to bilateral, regional and plurilateral forms of cooperation will have an impact on WTO dispute settlement even if the AB were to be reconstituted. The WTO has not managed to add much to its legislative arsenal since its creation. Besides a few sector-specific agreements negotiated in the late 1990s, the only comprehensive agreement it managed to conclude since 1995 is the Agreement on Trade Facilitation.

\subsection{Imbalance between rulemaking and adjudication}

The tensions created by the imbalance between consensus-based rulemaking and independent adjudication were already identified in the mid-1990s. The problem and its potential repercussions were clearly elucidated by Barfield (2001). He identified two concerns. First, instances where the AB would "legislate" issues that could not be resolved because of the inability of the membership to achieve consensus. Second, adjudication of disputes on matters that are highly divisive (political) - what Hudec (1980) called "wrong cases". Barfield cites various trade practitioners, including the current DeputyDirector General of the WTO, Alan Wolff, who is quoted stating (p. 118):

[The main problem of the current system is] the inappropriateness of placing on dispute settlement the burden of resolving major issues among the largest trading nations that in the final analysis cannot be resolved other than by negotiation among sovereign states ... There is no substitute for commercial diplomacy in relations among sovereign states. Resolution of differences where matters of national interest are concerned cannot be fobbed off for third party resolution in the trade arena, just as they cannot in the foreign policy context.

Barfield proposed both an ex ante- and an ex post mechanism to redress both types of problem cases. Ex ante, a 'deciding officer' (a WTO official entrusted with this function), would work with litigants to find mutually agreed solution instead of submitting disputes to formal adjudication. Ex post, a representative (but not majoritarian) sample of the WTO membership could decide on non-adoption of submitted reports. Today's discussions, viewed from this prism, sound like déjà vu. Barfield (2001) was not alone at pointing out the dangers of an unsustainable institutional imbalance. Others, notably Hudec (2002a), countered, legitimately so we might add, that the proposed solutions were open to potential abuse.

WTO Members would do well to reduce the prospects of the types of situations, identified by Barfield, arising. An important question is how to do so. Here, the WTO could learn from the doctrine of "non liquet", where a court can deny ruling on an issue if it finds that it has no law at its disposal to do so. In a way, the insistence of the United States to introduce Article 17.6 in the WTO Agreement on Antidumping, is a "mild" form of non liquet. The ICJ, being a court of general jurisdiction, is opposed, in principle at least, to non liquet. There is of course a difference between the ICJ and the WTO. The latter, per the DSU, is empowered to adjudicate only trade disputes and must do so without undoing the balance of rights and obligations as struck by the framers (Article 3.2 of DSU).

The question is who should decide whether a dispute put forward is a case of non liquet? While we recognize that a WTO panel (or the AB if cases are appealed) dealing with the specific dispute may be reluctant to do so, asking adjudicators to do so may be the most straightforward approach. This would 
cover both instances where rules are unclear and cases where issues are raised that have a bearing on the functioning of the WTO contract but are not yet regulated at the multilateral level. The argument for adjudicators not stepping in for the WTO membership in the latter type of situations is particularly strong. In such instances the WTO membership must address the matter. As discussed further below, a way of putting the burden on the shoulders of the membership as opposed to the adjudicative function would be to clarify - as a procedural matter - that the AB should request the relevant WTO committees and bodies to clarify the pertinent commitments, if rulings hinge on the interpretation of the invoked provisions of a WTO agreement. This innovation would clarify that an implication of Art. 3.2 DSU is that non liquet applies, if there are gaps or serious ambiguity in the applicable rules. ${ }^{37}$

\subsection{Bringing the $21^{\text {st }}$ trade agenda into the WTO}

In the last 20 years, rulemaking on trade-related policies that are only partially covered by WTO agreements, or not at all, has been the domain of PTAs. Horn et al. (2010) documented this pattern over a decade ago for agreements involving the EU and the United States. A recent project by the World Bank confirms earlier research (e.g., Dür et al, 2014) that PTAs include many policy areas not addressed by the WTO and/or go further ('deeper') than WTO disciplines. ${ }^{38}$ Moreover, the EU and the United States are no longer the primary drivers of this trend. ${ }^{39}$ Many countries are using PTAs to agree on rules of the road for policies where the WTO is missing in action. In some of these areas, subsets of WTO members have launched plurilateral "joint initiatives" and "dedicated discussions" but to date these have not (yet) managed to move beyond deliberation to binding legal texts. That has become the domain of PTAs. The challenge for the WTO is to become a forum for negotiation of meaningful plurilateral agreements and multilateralization of specific dimensions of PTAs.

Doing so will require a shift away from the staple of GATT and the (failed) Doha round negotiations: specific reciprocity. In traditional GATT rounds a central part of the agenda concerned reciprocal exchange of market access concessions. This technology is less effective as a basis for cooperation to attenuate the effect on trade of non-tariff measures (NTMs) that reflect domestic regulatory choices. Other approaches to internalizing policy externalities are required because it is not possible to "cut" domestic regulation $\mathrm{A}$ by $\mathrm{x} \%$ in exchange for an equivalent "cut" in foreign regulation $\mathrm{A}$, let alone to exchange a "cut" in regulation A for a "cut" in regulation B. In the Uruguay round, specific reciprocity was complemented by 'diffuse' reciprocity encapsulated in the single undertaking (Wolfe, 2009): negotiation of a package deal spanning many issues, with developing countries accepting TRIPS disciplines in exchange for better market access. The potential for such trades has declined, given low applied tariffs in most major economies and the increasing relative importance of differences in domestic regulation as a perceived source of negative international spillovers. ${ }^{40}$

There is a further complication. Except for TRIPs, WTO members are free to design their policies if they apply them in non-discriminatory manner insofar as they affect trade. Unlike tariffs, the current negotiating model does not make room for "binding" domestic policies. This means, that, if at all, reciprocity will obtain only at the time the negotiation occurs. Since WTO members retain the right to change their policies in the future, reciprocity is only accidental at any point in time after the original negotiation, as policies can become more restrictive as long as they apply in a non-discriminatory

37 An alternative approach could be to call on a group of eminent personalities to provide guidance in instances where there is ambiguity in the rules. This route was adopted in the CETA which provides for an expert group to provide guidance on the applicability of the prudential carve out for financial services. See Cantore (2018).

38 Hoffman et al. (2019); Mattoo et al. (2020).

39 The CPTPP is a prominent example, as are the many agreements negotiated by countries such as Australia, Singapore, Mexico, Chile, etc.

40 This is illustrated by the Global Trade Alert initiative, which documents that tariffs account for less than one-third of all trade-distorting measures imposed since 2008, with a large share of such measures reflecting antidumping and similar contingent protection instruments allowed by the WTO. See https://www.globaltradealert.org/. 
manner. Reciprocity, under the circumstances, becomes a dead letter the day after concluding the original negotiation.

Commitments on nondiscriminatory NTMs require a different logic. It becomes necessary to determine areas in which governments have similar goals, seek to agree on what makes for good policy in a given area, and to accept that governments may use different approaches to pursue similar goals. This is not at all straightforward as countries may have different goals and disagree on what makes for good policy. It is, therefore, not surprising that cooperation on domestic regulation occurs among likeminded players in plurilateral settings. These include deep PTAs as well as sector-specific cooperation among national regulators outside trade agreements (Hoekman and Sabel, 2019). Examples include huband-spoke arrangements in which a country or PTA-bloc (e.g., the EU) conditions trade on the effective implementation of regulation in exporting countries ("spokes") that is either identical or deemed to be equivalent to the applicable domestic regulatory regime in the importing or consuming jurisdiction. EU adequacy decisions regarding data protection that permit free cross-border data flows are an example of such 'conditional flow' regimes (Ferracane, 2017; Mattoo, 2018). The EU timber importation regime the Forest Law Enforcement, Governance and Trade (FLEGT) program - is another example (Overdevest and Zeitlin, 2018).

Pursuit of agreements under WTO auspices that plurilaterize such cooperation would help ensure the organization stays relevant. One dimension of the 'value proposition' offered by the WTO in this regard is in the area of enforcement, as new (plurilateral) agreements will need to have conflict resolution mechanisms. Determining how the WTO judicial function can and should apply to future plurilateral agreements and where other mechanisms such as the specific trade concern process used in some WTO committees (Wolfe, 2020a) or recourse to expert advice (Hoekman and Sabel, 2019) are more appropriate to address compliance and implementation concerns is an important dimension of the challenge confronting WTO members. This raises questions that require governments to consider whether to stick with the presumption that the State is the primary actor when pursuing multilateral cooperation. Presently, the degree to which business has a voice in determining national priorities and supporting implementation of agreements is strictly up to governments to determine. This is far from efficient, as business organizes itself in GVCs (global value chains) that span many countries. Creating direct channels of communication would enhance the prospects of making business organizations part of the 'production function' in monitoring implementation of agreements and identifying opportunities for improving cooperation across jurisdictions (Hoekman, 2014).

\section{Suggestions, Narrow and Less So}

The foregoing implies WTO members need to act on two fronts: address the dispute settlement crisis and re-ignite the legislative function. The latter will depend in part on the former, as plurilateral agreements will require enforcement mechanisms.

\subsection{The narrow dispute settlement crisis}

In what follows, we assume, consistent with the survey response reported in Fiorini et al. (2020), that the WTO membership continues to be in favour of a two-instance compulsory third party adjudication. We further assume that voting to commence the process of appointing new $\mathrm{AB}$ members ${ }^{41}$ is not in the cards, reflecting fears this will set a precedent and potentially confront WTO members with unwanted outcomes in other areas down the road.

41 See Petersmann (2019) for an argument that this would have been the appropriate response to the US decision to block all new $\mathrm{AB}$ appointments. 
The simplest way to resolve the $\mathrm{AB}$ crisis would be to ask the United States what would be required for it to withdraw its blocking veto. WTO members did this repeatedly during 2019 to no effect. There are good reasons to believe that some of the US concerns were either ex post facto justifications or diversions. An example is the alleged overstepping of the 90-day deadline for rulings imposed by the DSU. Johannesson and Mavroidis (2017) show that the AB has generally violated the statutory deadlines by only a few days on average. Panels routinely have incurred much longer delays. On average, panels issue reports 15.5 months after their establishment. The statutory deadline is 6-9 months. If the United States cares about respect for deadlines, it should chastise panels. It has not.

A consistent feature of US criticism has been the haphazard treatment of the idiosyncratic standard of review embedded in the WTO Agreement on Antidumping. Article 17.6 of this agreement, introduced at the insistence of the US delegation in the Uruguay round, was meant to act as a deferential standard in favour of interpretations adopted by investigating authorities if panels find there is more than one permissible interpretation. Cartland, Depayre and Woznowski (2012) argue that the US Uruguay Round delegation's understanding was that Art. 17.6 served as a green light for 'zeroing', a practice designed to inflate dumping margins. ${ }^{42}$

We have little sympathy for antidumping as an instrument of protection, and even less for the practice of zeroing. Our antipathy is predicated on economic first principles. Whatever one's views on this matter, $\mathrm{AB}$ members are agents per Article 3.2 of DSU, and must not undo the balance of rights and obligations negotiated by the principals. The $\mathrm{AB}$ was required to give meaning to Art. 17.6. The US critique is that they only paid lip service to it. This critique is well founded. Panels and the AB have routinely repeated a statement to the effect that the Art. 17.6 standard of review is not at odds with the generic standard of review, and, as a result, have not seriously engaged with Article 17.6. It is likely that little, if anything, would have changed with respect to zeroing case law had the AB approached the interpretative issue from the angle of Article 17.6. It is unfortunate it did not do so. ${ }^{43}$

Linked to the zeroing discussion is the claim by the US that the AB has been overstepping its mandate. In the case of zeroing disputes, it is a matter of debate whether the $\mathrm{AB}$ overstepped its mandate in its handling of Article 17.6. ${ }^{44}$ While it may have misconstrued the agreed standard, its actions are hardly a clear-cut case of diminishing rights agreed and acknowledged by the framers. There was no widespread agreement over zeroing as otherwise the text would say so explicitly. Art 17.6 is an example where negotiators papered over a disagreement, raising the question if and how panels and the $\mathrm{AB}$ should address such instances. We return to this below.

Leaving zeroing aside, there are other cases where the $\mathrm{AB}$ has clearly overstepped its mandate, even though no WTO Member - including the United States - has complained about it. Any time the AB "completes the analysis" it effectively deprives the membership of the two-instance adjudication they had agreed upon. Because of the "incompleteness" of the original WTO contract, staying within the mandate is probably the hardest DSU discipline for the AB to observe. In case of egregious violations, like the case law concerning "completing the analysis", it might be easy to pronounce in favour of disrespect of the mandate. ${ }^{45}$ Most issues however are not egregious. The law vs. facts dichotomy is an

42 The views expressed on this matter by these authors are particularly salient because the first two coauthors were Uruguay round negotiators and the third was a GATT Secretariat member in charge of antidumping. Nevertheless, the three authors might be overstating their claim here. The negotiating record reveals little explicit discussion on zeroing. The US concerns were wider than that, and this is why the United States requested that a deferential standard of review be inserted in both the antidumping and subsidies context. A declaration agreed to this effect called for eventually symmetric treatment of the two agreements, even though the membership never managed to agree to "export" the Article 17.6 standard into the SCM Agreement.

43 Mavroidis and Prusa (2018).

44 See, e.g., Zhou and Gao (2019) on the issue of overreach and references to the legal literature on this question.

45 This is not to deny there are factors that help understand why such outcomes might arise in practice, e.g., the absence of remand or the need for the $\mathrm{AB}$ to issue rulings within short time limits. 
illustration to this effect. Factual issues can be presented as legal issues with some imaginative expression. This might explain why, notwithstanding the sympathy some WTO Members may have with the United States views on this score, there is no agreement on the appropriate course of action to address the situation.

Re-negotiation of the zeroing issue is probably the wisest path forward, as case law continues to be erratic on this matter. ${ }^{46}$ An alternative approach would be to exempt antidumping and countervailing duty cases from appellate review, as has been proposed by Hillman (2018) and Schott and Jung (2019). While this would address one major source of US ire against the AB, this 'pragmatic'solution' falls short in resolving the more fundamental problem that arises when rules are fuzzy or leave gaps. Where they are not clear, rules should be clarified by the WTO membership. The same is true more generally with respect to claims that the $\mathrm{AB}$ has overstepped its mandate in filling gaps. As noted by McDougal (2018) and Payosova et al. (2018), such matters require action by WTO members to clarify the applicable rules. One way to reduce the pressure on the AB in such instances would be for the WTO membership to require the $\mathrm{AB}$ not to rule on matters where the rules are unclear (as is already required by Art. 3.2 DSU which prohibits the AB from undoing the balance of rights and obligations reflected in WTO agreements) and go beyond this by requiring the AB to ask the WTO bodies that are responsible for the implementation of the agreements invoked in a dispute to clarify the rules or fill a gap. ${ }^{47} \mathrm{In}$ parallel with measures to further professionalize adjudication (see below) that should reduce the likelihood that adjudicators do not adhere to Art. 3.2. for idiosyncratic reasons, this should substantially attenuate concerns that the $\mathrm{AB}$ might exceed its mandate.

\subsection{Non Bis Peccatur (A Cat Won't Sit on a Hot Stove Twice?)}

Fixing the $\mathrm{AB}$ crisis requires consensus as dispute settlement applies to all members. This does not imply that all WTO members must engage actively: the way to consensus starts with agreement among the relatively small group of WTO members that is most concerned with a functioning conflict resolution mechanism, that is, the large trading powers that are customarily the most active participants (see Section 2 above). Such agreement is not only necessary but probably sufficient, given that the United States has made clear that veto-players have nowhere to hide by becoming the ultimate veto player itself. The US has demonstrated it is no longer willing to play the role of a benign hegemon and accept that other (developing country) WTO members play linkage games.

In our view, corrective actions to introduce stronger checks and balances on the $\mathrm{AB}$ must operate $\mathrm{ex}$ ante. Flirting with 'back end' solutions, such as introducing a mechanism to correct the $\mathrm{AB}$ ex post, can only give $\mathrm{AB}$ members the wrong incentives. Panels and the $\mathrm{AB}$ unavoidably will have substantial discretion, as they must interpret one incomplete contract (the WTO) by using another incomplete contract (the Vienna Convention on the Law of Treaties, which does not assign specific weights to its various elements). Feasible contracts like the GATT/WTO are obligationally incomplete ex ante (Horn, Maggi and Staiger, 2010). If it were possible to write a more complete contract, that would have happened. By this, we do not deny that marginal improvements are impossible. To the contrary, we have already argued in favour of a legislative solution to clarify the status of zeroing in WTO law. Intelligent legislators are in constant reactive mode and 'complete' the contract gradually based on (learning from) experience.

46 In April 2019, the panel on US-Price Differential Methodology (DS534) went head on against 25 years of AB case law and found that zeroing can be WTO-consistent.

47 This is exactly what the panel on US-Softwood Lumber IV did, when facing the question of out-of-country benchmarks under Article 14 of the SCM (Agreement on Subsidies and Countervailing Measures). It expressed its sympathy with the US view, but declared it had no power to undo the balance of rights and obligations as struck by the framers. The AB did just that. The United States however, did not complain of aggressive overstepping of the mandate (which it clearly was) by the $\mathrm{AB}$, since it had profited from the decision. 
Greater selectivity when appointing adjudicators and paying more attention to the organizational aspects of dispute settlement processes could do much to prevent the type of situation that has arisen. Experienced and highly qualified adjudicators would not have totally neglected Art. 17.6, for example. In the case of the GATT, organizational aspects of adjudication were to be part of the International Trade Organization (ITO), which never saw the light of day. This explains the original birth defect. Subsequently, the focus was on rulemaking and legal institutions, not on the organizational aspects of dispute settlement. Davey (1987) provides an excellent account of the evolution of GATT dispute settlement until the launch of the Uruguay round. His narrative makes clear that efforts concentrated in crystallizing practice into legal documents of varied legal value. This is not to say that the system did not work well. Indeed, as Hudec (1993) explained in his monumental study of GATT dispute settlement, it is largely thanks to GATT's pragmatic resolution of disputes that the system evolved into compulsory third-party adjudication following the Montreal Mid-Term Review of 1988.

As the membership gradually became more heterogeneous, it became more difficult for the GATT to operate as a relational contract. Hudec (1993) shows that the rate of adoption of panel reports in the post-Tokyo round era fell dramatically. By the time of the Uruguay round, GATT contracting parties had accumulated extensive experience regarding the vicissitudes of dispute settlement and the problems posed by the absence of detailed procedures. They also were fully aware that they should focus on organizational aspects as part of the establishment of the WTO. Importantly, they had also acquired first-hand experience with 'back end' solutions - the notion that greater ex post political review of dispute settlement and 'member control' could address perceived adjudication mistakes. The best example is the transatlantic DISC dispute on taxation, where the GATT Council decided to undo in part the findings of the dispute settlement panel, only to provoke the wrath of the aggrieved party, the United States. Hudec (1988) and Jackson (1978) provide excellent accounts of the litigation, and its eventual aftermath. This experience helped incentivize the process of shifting towards a more rules-based dispute resolution system. Those proposing 'back end' solutions today should be reminded of the scars the DISC litigation left on the GATT dispute settlement system. ${ }^{48}$

One would expect that, against this background, negotiations would focus on the organizational aspects of dispute adjudication, the neglected issue under the GATT. It was not meant to happen. This was not for lack of volition but because Uruguay round DSU negotiators had bigger fish to fry (or so they thought). Their efforts concentrated on addressing US unilateralism, with little to no effort devoted to organizing the work of panels and the AB (Mavroidis 2016b). It is high time this happened.

The following elements could usefully find their way into a future negotiation on WTO dispute settlement reform: ${ }^{49}$

- Professionalize the panel stage of the DSU by creating a standing roster of 15-20 permanent panelists, where:

- Panelists should serve for one long term of 8-10 years;

- Depending on criteria to be defined (new issues; value of disputes etc.), disputes are heard by divisions of 3 (relatively less important), or divisions of 7 (relatively more important);

- Decisions are taken by majority; and

- Dissenting opinions are published.

- Expand the $\mathrm{AB}$ to comprise 9 members as opposed to 7 (in recognition of the case load observed in recent years), with:

48 See Mavroidis (2016a) for discussion of this case. US business proposals made in December 2019 calling for an oversight body, including independent experts, do not constitute what we call back end solutions as they are limited to review and issuing a recommendation whether the $\mathrm{AB}$ has violated one of the Walker principles (discussed below). See https://insidetrade.com/daily-news/business-pro-trade-groups-propose-fixes-wto-appellate-body.

49 Some of these suggestions have also been made by other observers, see e.g., Busch and Pelc (2009) and McDougal (2018). 
- Appointees serving one long term of 8-10 years;

- Appointments are on a full-time basis;

- Cases decided by divisions of three AB members;

- Decisions taken by majority vote;

- Dissenting decisions are published; and

- The collegiality requirement is maintained.

- To increase the prospects that qualified and experienced individuals are appointed as adjudicators, WTO members should establish a commission of eminent experts - a combination of lawyers, economists and experienced WTO practitioners who are well-versed in GATT/WTO dispute settlement. This group would be tasked with screening both the panelist and $\mathrm{AB}$ nominees put forward by WTO members and establishing whether proposed adjudicators are eligible for the proposed job.

- Article 255 TFEU $^{50}$ could serve as inspiration to this effect;

- The members of the commission should be decided on a consensus basis by the WTO membership;

- WTO members select adjudicators from the pool of candidates determined to be eligible for the respective position by the Commission.

- Both the $\mathrm{AB}$ members, as well as panelists, will have the right to appoint their clerks

- The number of clerks serving each judge will be decided ex ante;

- $\mathrm{AB}$ members may select only one clerk of their own nationality.

There is, of course, much more to think about when determining how to improve WTO adjudication. The above are basic axes that could help address some important dimensions such as the quality of judges, the incentives of adjudicators to please their nominating party, and potential confusion regarding the functions of the WTO Secretariat. Take the last point, and more specifically, the allegation that the Secretariat unduly influences the outcome of disputes. Nordström (2005) was the first to ask the question whether the WTO Secretariat behaved like "secretaries" or goes beyond this in holding the pen when drafting reports. Johannesson and Mavroidis (2015) build on Nordström's analysis to argue that given missing expertise and weak incentives, it is to be expected that the Secretariat is influential. That said, panellists and AB members have the last word. Although Pauwelyn and Pelc (2019) argue this is not the case de facto, irrespective of the extent to which the Secretariat is an actor in dispute settlement, there are good reasons to create stronger firewalls when it comes to dispute adjudication. Two distinct functions - providing advice to WTO members on legal issues and providing advice on the same issues to panels - are in practice conflated, and can easily be confused, casting doubt on the "impartiality" of panels, even if the bias is unconscious. ${ }^{51}$

50 Article 255 of the Treaty on the Functioning of the European Union (TFEU) reads as follows. "A panel shall be set up in order to give an opinion on candidates' suitability to perform the duties of Judge and Advocate-General of the Court of Justice and the General Court before the governments of the Member States make the appointments referred to in Articles 253 and 254. The panel shall comprise seven persons chosen from among former members of the Court of Justice and the General Court, members of national supreme courts and lawyers of recognized competence, one of whom shall be proposed by the European Parliament. The Council shall adopt a decision establishing the panel's operating rules and a decision appointing its members. It shall act on the initiative of the President of the Court of Justice."

51

Hoekman and Mavroidis (2020). The US business community has proposed "term limits for members of the Appellate Body secretariat of not longer than eight years, equal to the maximum term for an $\mathrm{AB}$ member, to rebalance power within the appeals process, give primacy to the reasoning of Appellate Body members and ensure staff help to write decisions, not make them." See https://insidetrade.com/daily-news/business-pro-trade-groups-propose-fixes-wto-appellate-body and Hirsh (2019). 
Our suggestions complement the principles proposed by New Zealand Ambassador David Walker to address US concerns with the operation of the AB (WTO, 2019b). These include ensuring that appeals are completed within 90 days; that Appellate Body members do not serve beyond their terms; that precedent (case law) is not binding; facts cannot be the subject of appeals; the AB be prohibited from issuing advisory opinions; and that its findings cannot add obligations or take away rights provided by the WTO Agreements. All of these are fully consistent with - and indeed often echo - what is in the DSU. For this reason, they should be amenable to all WTO Members and serve as the basis for the substantive agreement needed to address the core US concern - credible measures to ensure the AB will stick to its mandate.

One lesson from recent events is that more political oversight and interaction between WTO members and a reconstituted $\mathrm{AB}$ is needed. Some type of advisory review body, as proposed by the US business community, with a mandate to assess and report on compliance by the Appellate Body with the "Walker Principles" 52 may help provide greater assurance that matters relating to the performance of the $\mathrm{AB}$ can be given greater attention in the DSB. However, at the end of the day insofar as members believe the $\mathrm{AB}$ is exceeding its mandate (e.g., in filling gaps) this calls for (re-)negotiating the substantive provisions of specific agreements.

In thinking about how this can be encouraged, it is helpful to distinguish between substantive rules on the one hand and organizational-cum-procedural matters on the other, in particular the operation of WTO bodies tasked with implementation of WTO agreements. In the area of dispute settlement one such procedural change would be to permit the $\mathrm{AB}$ to remand cases back to panels in cases where panels exercised judicial economy and the $\mathrm{AB}$ reverses a panel decision. ${ }^{53}$ Another, more important change, would be to require the $\mathrm{AB}$ to ask the relevant WTO bodies to clarify the applicable substantive rules in instances where there are gaps or rules are unclear (Payosova et al. 2018).

Such changes need approval from the membership. i.e., the DSB. Extensive preparatory work will be required before such proposals can be placed on the DSB agenda for a decision. As these are matters that relate to the operation of the WTO, preparing the ground should involve the active engagement of the Director-General as an 'honest broker' and the leader of the organization. Insofar as the large traders and most of the membership supports such procedural changes, if necessary, recourse can be made to voting, as foreseen by Art. IX WTO. In practice, we believe that the need for voting will be limited if procedural changes are well prepared and supported by the key players.

Sceptics might argue that the prospects of any such agreement in the current context are rather dim. We do not underestimate the difficulty associated with re-establishing trust among the large players, a sine qua non for agreement on procedural DSU reforms. In our view, the Walker process is a good illustration that consultations and dialogue among WTO members can identify areas where there is broad support for considering specific actions of a procedural nature. While no action on Ambassador Walker's report proved possible before the demise of the AB in early December 2019, the process clearly demonstrated that many WTO members were willing to revisit Art. 17 DSU (which leaves the elaboration of its working procedures to the $\mathrm{AB}$ to determine) as well as other procedural provisions in the DSU.

52 US business groups suggest such a body to comprise the chairs of key WTO committees plus four independent trade law experts. These suggestions are consistent with the thrust of proposals made by the European Union, China, Canada, India, Norway, New Zealand, Switzerland, Australia, Republic of Korea, Iceland, Singapore and Mexico in a 26 November 2018 communication to amend the DSU to address the procedural issues raised by the United States (see WT/GC/W/752 and EU, 2018).

53 This would enhance the efficiency of the dispute settlement process by avoiding the parties having to launch a new case to address the arguments that the panel did not consider. 


\subsection{The Broader Challenge: Re-invigorating WTO Legislative Action}

Resolving the $\mathrm{AB}$ crisis is only one part of the challenge confronting WTO members. The payoff to reconstituting the appellate function depends on the ability of the WTO once again to become a venue for rulemaking on contested policies that generate large negative spillovers. A first step should be for the membership to recognize that the Doha round is dead. This simple move will, in and of itself, liberate negotiating forces. Although the post Buenos Aires plurilateral negotiations and discussions are a positive vital sign, they are impeded by the overhang of the Doha Round and the continued insistence of many members that the round must be completed and the post Buenos Aires 'joint initiative' groups should not be supported. This is an important factor explaining why participation in some of these groups is relatively limited. The issues that were on the Doha agenda are important but moving forward on them will require a re-designed work program that includes both the joint initiatives and additional ones to be determined by groups of WTO members.

For the reasons mentioned above, reliance on the traditional 'first-difference' reciprocity formulae used in past trade negotiations does not work for many of the regulatory issues that may generate crossborder tensions. This is true both for policies affecting the digital economy and trade in services as well as "old" industrial policy instruments such as discriminatory tax/subsidies that are increasingly used by the major trading powers. Internalizing cross-border spillovers of both types of policies requires agreement among the large trade powers that are the main source of negative externalities.

The obvious way forward on the rulemaking front after more than a decade of fruitless Doha round stalemate was taken up at the end of 2017 with the launch of plurilateral talks ('joint initiatives'). Four plurilateral groups are currently active under WTO auspices, spanning e-commerce, domestic regulation of services, investment facilitation and measures to support the ability of small firms to use the trading system They have the potential to address policies that matter to both businesses and their workers and communities as well as to consumers. Businesses seek a reduction in policy uncertainty and the compliance costs associated with regulatory heterogeneity, while consumers have an interest in reducing the cost of goods and services conditional on satisfaction of national regulatory standards, including sensitive matters such as data privacy.

The WTO groups are dealing with subjects that potentially can do much for both sets of stakeholders. For these green shoots to take root and create fertile ground for additional initiatives - including efforts to revisit Doha round issues - they must generate meaningful outcomes. Given that the starting point is not very propitious, with the US and China engaged in a trade war that is unlikely to conclude soon, rising geopolitical tensions, and one of the negotiating groups (on e-commerce) spanning topics where the major players are far apart, realism suggests that progress will be incremental at best. But as long as enough can be achieved in the different ongoing group-based discussion, and WTO members complement this with a concerted effort to resolve the dispute on dispute settlement, this will establish a basis for engagement on other subjects, including those that lie at the heart of current trade tensions such as industrial subsidies, the operation of SOEs (state-owned enterprises), and taxation of domestic sales by foreign companies, and that are on the immediate horizon, notably the use of trade policy as an element of addressing climate change.

A necessary condition for negotiations on these subjects is that parties have a common understanding (and thus knowledge base) that informs deliberations. Absence of trust among the major players needs to be recognized - a process centered on establishing a factual basis and common understanding of what governments are doing in a specific area, the goals they are pursuing and analysis of the order of magnitude of associated spillovers - both negative and positive - can create the grounds for negotiation. This calls for greater engagement with - and support of - associated epistemic communities. In the GATT years, when contracting parties were confronted with the question whether MFN could serve the interests of developing countries, they turned to two Nobel Prize economists (James Meade, and Jan Tinbergen) and a well-known Brazilian economist (Roberto de Oliveira Campos), who under the chairmanship of Harvard economist Gottfried Haberler provided a well-informed report that informed 
a decision on this matter. Engagement with stakeholders with an interest and knowledge of trade in services was an important element in informing the eventual design of the General Agreement on Trade in Services.$^{54}$ A similar story applies to the more recent example of the Agreement on Trade Facilitation which drew on extensive knowledge of good practices in the area of customs and border management developed in the World Customs Organization and development agencies. The case of the TFA is particularly salient because it is the only success story in negotiating new disciplines realized in the WTO's first 25 years. ${ }^{55}$

The WTO community has taken distance from using outside experts and building bridges to the relevant epistemic communities. Compared to the GATT, WTO members have less frequent recourse to outside expertise - indeed it not much of an exaggeration to argue that it has largely disappeared altogether. While there is some engagement with 'stakeholders' and WTO bodies bring in national regulators, representatives of specialized international organizations and industry on an ad hoc basis, there is only limited effort to engage with relevant systemic communities on a regular basis. The WTO will need all the help it can get to prove equal to the challenge of designing new plurilateral agreements and sustaining multilateral dialogue and cooperation. Political volition is a sine qua non, but not a sufficient condition for well-thought institutional arrangements that are equal to contemporary challenges. There is a lot of thinking regarding the future of the WTO in stakeholder circles, and the WTO can only profit by inviting this discussion to take place within its confines.

Low hanging fruit for additional plurilateral initiatives to begin to shorten the distance between the WTO and the 350 PTAs that are in force would be to establish a forum to provide more transparency (information) on the experience of PTAs and help (groups of) WTO members identify sectoral or horizontal dimensions of PTAs that may lend themselves to possible multilateralization. As things stand, PTAs must be notified to the WTO before they enter into force, with members of the (prospective) PTA providing information on the provisions of the agreement. The WTO does not generate information on what happens ex post, notably the effects of implementing provisions that go further than the WTO. Doing so would create a channel of communication between PTAs and the WTO, and a basis for evaluating the potential for gradually multilateralizing some of the content of PTAs. This can - and indeed often must - involve plurilateral agreements as not all WTO members will want to play, and some of those that do may not be capable of doing so because they cannot satisfy specific participation standards.

It is past time to re-think the overall approach taken towards PTAs given that this is where the action has been for most of the existence of the WTO. Much more attention should be given in WTO Committees to the operation of deep PTAs in practice with a view to mutual learning and identifying areas where there is potential interest in multilateralizing PTAs approaches through open plurilateral agreements under the umbrella of the WTO. Inspired by Article 21.6 of DSU (which keeps under surveillance cases where recourse to retaliation has been authorized), the WTO should develop a monitoring mechanism of PTAs that have been reviewed by the CRTA (Committee on Regional Trade Agreements) and encourage engagement in sector- and policy-specific WTO bodies on the experience and lessons that emerge from cooperation in their respective areas in different PTAs. A Transparency Mechanism 2.0, inspired by the original, ${ }^{56}$ with the mandate to create a regular flow of information between PTAs and the WTO would help members to determine areas of PTA-based cooperation that could be multilateralized (extended to encompass non-PTA signatories). This could take the form of open plurilateral agreements (Hoekman and Sabel, 2019), or, where feasible - as was the case with trade facilitation - the creation of new multilateral agreements.

\footnotetext{
54 See, e.g., Drake and Nicolaidis (1992). Mavroidis (2020) discusses the GATS negotiations at length.

55 Hoekman (2016) discusses the TFA experience in some depth.

56 WTO Doc. WT/L/671 of December 18, 2006.
} 


\section{Concluding Remarks}

The current crisis should provide the impetus to re-configure the WTO by addressing home truths that the world trading community has been avoiding at the risk of (further) eviscerating the policy relevance of the WTO. The wider (WTO) and narrower (AB) crisis are related. WTO members should begin preparing the ground to lay the foundations for addressing both the narrow and the wider challenge confronting the organization.

The dispute settlement crisis is an opportunity to address concerns regarding the quality of output of WTO courts, and their respect of the institutional mandate. To this effect, we have advanced some proposals aiming to ensure the independence and impartiality of WTO courts, and respond to the stated preference of the institutional stakeholders and the business community (as evidenced in the responses to the survey that we have conducted) for a two-instance compulsory third-party adjudication that will predictably interpret the agreed trade agreements. Efforts to pursue 'plan B' approaches to put in place appellate type review on a plurilateral basis, as is being pursued by the $\mathrm{EU},{ }^{57}$ are understandable responses to the deadlock but do not engage with the fundamental problems that have been raised by the US. Plan B responses are also second best as they do not fulfill the role the AB was meant to address: to oversee all of WTO case law.

Resolution of the AB impasse requires the subset of WTO members most concerned with effective dispute settlement to launch negotiations on specific procedural dispute settlement reforms, building on the 'Walker principles'. ${ }^{58}$ Professionalization of WTO dispute settlement, as we propose above, will only be possible if accompanied by measures to ensure that the core US concern is addressed, i.e., that adjudicators do not exceed their mandate and engage in rule making. This can be achieved by putting in place clear guidance for the $\mathrm{AB}$ that require cases where findings hinge on interpretation of unclear treaty provisions, call for 'gap filling' or establishment of rules to be sent to the pertinent WTO bodies with the request to clarify or negotiate the applicable rules. If it is not possible for the membership to do so, the dispute simply will not be resolved.

This is necessary, not sufficient to revitalize the WTO. There is an urgent need for renewed substantive rulemaking. To date, the United States has been the outlier in using trade policy unilaterally as a stick to induce changes in foreign economic policies and to enforce what it regards as its trade rights, first during the eighties through the notorious Section $301,{ }^{59}$ and more recently vis-à-vis China ${ }^{60}$ The EU may be beginning to move in this direction, as the recent proposal to "take justice in its own hands" in matters of trade shows. ${ }^{61}$ It was a strong commitment to multilateralism during the Uruguay round that put an end to US aggressive unilateralism. A similar commitment is necessary to avert the renewed US tendency in this regard to kindle emulation and move the trading system back to the past.

The WTO reform discussions that some members have engaged in since 2018 provide a basis on which to build. This must confront the core working practices of consensus and special and differential treatment (Bertelsmann Stiftung, 2018; Hoekman, 2019). In doing so, we believe it is helpful to differentiate between process and procedure on the one hand, and substantive disciplines on the other. There are very good reasons for consensus when it comes to (changes in) the substantive rules of the game that apply to specific trade-related policies. WTO members should be able to decide not to join a consensus that alters their rights and obligations if they perceive this would be averse to their interests.

57 See footnote 8 supra.

58 A necessary precondition for this in the short term may be an agreement dealing with disputes regarding the US invocation of Section 232 of the US trade expansion act of 1962, which permits the imposition of trade restrictions to safeguard US national security.

59 Bhagwati and Patrick (1991) provide an excellent discussion.

60 The "Phase One" deal between United States and China, which includes various transparent violations of WTO law is available at https://assets.bwbx.io/documents/users/iqjWHBFdfxIU/rVaHxDBUtdew/v0.

61 See COM (2019) 623 final of December 12, 2019 and Stewart (2019). 
But consensus should not enable countries to block others that wish to explore cooperation in an area. Nor should consensus apply to processes and the day-to-day business of WTO bodies such as whether to invite outside experts to inform the deliberations of a committee (Wolfe, 2020b).

This applies to dispute settlement as well. Procedural changes in the implementation of DSU by the institution lie at the heart of any resolution of the $\mathrm{AB}$ crisis. Such changes require deliberations and decisions by the membership to implement specific reforms to improve the operation of the DSU. If necessary, such process-related changes should be subject to a vote, as envisaged by Art. IX WTO. Doing so is not in the DNA of the organization, for good reason. We strongly support the principle of consensus-based decision making when it comes to substantive rules and negotiated rights and obligations. But we are also of the view that voting on procedural reforms that improve the operation of the institution without affecting the rights and obligations of WTO members should not give rise to concerns this is a slippery slope. If institutional/procedural reform proposals are well prepared informed by consultations and supported by the good offices of the DG - voting may not be needed in any event.

The $12^{\text {th }}$ Ministerial Conference of the WTO (MC12) in mid-2020 provides an opportunity to go beyond taking stock of progress made in the various plurilateral groups and some of the agenda items left over from MC11 - notably an agreement to discipline fish subsidies. Ministers should launch a work program on policies that are perceived to give rise to serious cross-border spillovers and that are leading to trade conflicts (or can do so). Examples include subsidies, SOEs, and climate-motivated trade policies. A precondition for negotiations and agreements on such policies is a common understanding of the state of play and the extent and incidence of associated cross-border spillovers. This was standard operating procedure for the organization in the past when considering the set of issues that should be on the agenda. An example was of this type of process was pursued after the failed 1982 GATT ministerial. It provided the basis for the inclusion of services on the agenda of the Uruguay Round in 1986 and the eventual negotiation of the GATS. Similar efforts are needed today.

Compared to the GATT, the WTO is much more transparent and engages more with civic society. This engagement is mostly one way, revolving around providing information. Consultations with stakeholders are left to WTO Members, which may or may not engage with domestic interest groups in defining their positions. What is missing is serious, informed dialogue, based on solid, actionable information provided by those who trade - industry and consumer groups - and those who can assess the domestic and cross-border effects of policies - independent analysts in academia and research institutes and international organizations. Creating a permanent roundtable through which representatives of the business community and civic society can raise issues and provide information and feedback to governments on the implementation of trade policies would help ensure that WTO members focus on issues that matter to those who utilize and are affected by the trading system.

We end with four suggestions for WTO members to consider at MC12 with a view to re-invigorate multilateral trade cooperation.

- First, create working groups to consider priority areas for multilateral rulemaking, with a mandate to assess the magnitudes of systemic negative spillovers associated with national policies in areas that are not or inadequately covered by the WTO. Establishing a common understanding and baseline data on national policies that are feeding current trade tensions or that are likely to do so in the near future is a precondition for negotiating agreements, whether on a plurilateral or multilateral basis. ${ }^{62}$

- Second, consider changes in the governance framework to support greater use of open plurilateral agreements, as we have argued for in Hoekman and Mavroidis (2015) and Hoekman and Sabel (2019). Variable geometry is not only unavoidable but for many issues is desirable, given differences in social preferences and national priorities and capacities. It is important that there be

62 This is particularly important for subsisdies - see Hoekman and Nelson (2020). 
greater clarity on the 'rules of the road' that should apply to such agreements to ensure that they are consistent with, and supportive of, the rules-based multilateral trading system. While a few members only will usually carry the ball to the next legislative frontier, those who initially decide not to participate should be assured that they can do so at a later date (should they desire to) without having to pay a more expensive entry ticket than the incumbents did.

- Third, re-think the function and operation of WTO committees. It is there that the law-making trading community meets. It is from there that the re-invigoration process should start. The committees should be mandated to establish connections with the relevant epistemic communities and stakeholders: trade practitioners worldwide, the business community and civic society actors, including other international organizations. ${ }^{63}$ Such a revamp could relieve the pressure on formal dispute settlement (Wolfe, 2020a) and facilitate deliberation on opportunities to expand multilateral cooperation. An example where such opportunities exist is to profit from ongoing experimentation in PTAs (Hoekman, 2014).

- Finally, on dispute settlement narrowly defined, take action to place the burden of completing the contract where needed to resolve a conflict on the WTO membership, not the dispute settlement bodies. This could be done by requiring adjudicators to ask the WTO bodies responsible for overseeing implementation of the agreements invoked in a dispute to do so in cases where the substantive rules are unclear. Moves in this direction and consideration of the complementary institutional-cum-procedural changes we have proposed would address the concerns raised by the US and improve the implementation of the DSU.

Action along these lines at MC12 could help to prepare the ground for new thinking and bring a muchneeded breath of fresh air into the WTO. For multilateral cooperation to occur, it must be meaningful in addressing the ever-changing priority issues that affect those who rely on a robust system of multilateral rules. Our proposals are meant to help do that, and in the process support the revitalization of the WTO. If the membership is bold enough to adopt proposals along these lines, we might start seeing some light at the end of the tunnel.

63 Bertelsmann Stiftung (2018) and Wolfe (2018; 2020a,b) discuss specific suggestions pertaining to the operation of WTO bodies. 


\section{References}

Barfield, Claude. 2001. Free Trade, Sovereignty, Democracy: The Future of the World Trade Organization, American Enterprise Institute: Washington, D.C.

Bertelsmann Stiftung. 2018. "Revitalizing Multilateral Governance at the World Trade Organization," Report of the High-Level Board of Experts on the Future of Global Trade Governance,

Bertelsmann Stiftung. At: https://www.bertelsmannstiftung.de/fileadmin/files/BSt/Publikationen/GrauePublikationen/MT_Report_Revitalizing_Multil ateral_Governance_at_the_WTO.pdf.

Bhagwati, Jagdish, and Hugh T. Patrick. 1991. Aggressive Unilateralism, University of Michigan Press: Ann Arbor, Michigan.

Bown, Chad and Bernard Hoekman. 2008. "Developing Countries and Enforcement of Trade Agreements: Why Dispute Settlement Is Not Enough," Journal of World Trade 42(1): 177-203.

Bronckers, Marco and Nico van den Broek. 2005. "Financial Compensation in the WTO," Journal of International Economic Law 8(1), 101-26.

Busch, Marc and Krzysztof Pelc. 2009. "Does the WTO Need a Permanent Body of Panelists?" Journal of International Economic Law, 12(3): 579-94.

Cantore, Carlo. 2018. The Prudential Carve-Out for Financial Services: Rationale and Practice in the GATS and Preferential Trade Agreements. Cambridge: Cambridge University Press.

Cartland, Michael, Gérard Depayre, and Jan Woznowski. 2012. Is Something Wrong in the WTO Dispute Settlement? Journal of World Trade, 46: 979-1015.

Condon, Bradly J. 2018. "Captain America and the Tarnishing of the Crown: The Feud Between the WTO Appellate Body and the USA," Journal of World Trade 52(4): 535-556.

Davey, William J. 1987. Dispute Settlement in GATT, Fordham International Law Journal, 11: 51-102.

Drake, William and Kalypso Nicolaidis. 1992. "Ideas, Interests, and Institutionalization: 'Trade in Services' and the Uruguay Round," International Organization, 46(1), 37-100.

Dür, Andreas, Leonardo Baccini and Manfred Elsig. 2014. "The design of international trade agreements: Introducing a new dataset," The Review of International Organizations, 9(2): 353-75.

Ehlermann, Claus-Dieter and L. Ehring. 2005. "Decision-Making in the World Trade Organization: Is the Consensus Practice of the World Trade Organization Adequate for Making, Revising and Implementing Rules on International Trade?" Journal of International Economic Law 8(1): 51-75.

European Union. 2018. "WTO reform: EU proposes way forward on the functioning of the Appellate Body,” At: https://ec.europa.eu/commission/presscorner/detail/en/IP_18_6529.

Ferracane, Martina. 2017. "Restrictions on Cross-Border Data Flows: A Taxonomy," ECIPE Working Paper No. 1/2018, Brussels.

Fiorini, Matteo, Bernard Hoekman, Petros C. Mavroidis, Maarja Saluste, and Robert Wolfe. 2019. "WTO Dispute Settlement and the Appellate Body Crisis: Detailed Survey Results," at https://www.bertelsmann-

stiftung.de/fileadmin/files/BSt/Publikationen/GrauePublikationen/MT_WTO_Dispute_Settlement_ and_Appellate_Body_Crisis.pdf

Fiorini, Matteo, Bernard Hoekman, Petros C. Mavroidis, Maarja Saluste and Robert Wolfe. 2020. "WTO Dispute Settlement and the Appellate Body Crisis: Revealed Preferences and Insider Perceptions," Journal of World Trade, forthcoming. Available at: https://www.bertelsmannstiftung.de/fileadmin/files/BSt/Publikationen/GrauePublikationen/MT_WTO_Dispute_Settlement_ and_the_Appellate_Body_Crisis_Survey.pdf 
Hillman, Jennifer. 2018. "Three Approaches to Fixing the World Trade Organization's Appellate Body: The Good, the Bad and the Ugly," At: https://www.law.georgetown.edu/wpcontent/uploads/2018/12/Hillman-Good-Bad-Ugly-Fix-to-WTO-AB.pdf.

Hirsh, Bruce. 2019. "Resolving the WTO Appellate Body Crisis: Proposals on Overreach," paper commissioned by the National Foreign Trade Council (December).

Hoekman, Bernard. 2014. "Sustaining Multilateral Trade Cooperation in a Multipolar World Economy," The Review of International Organizations, 9(2): 241-260.

Hoekman, Bernard. 2016. "The Bali Trade Facilitation Agreement and rulemaking in the WTO: milestone, mistake or mirage?" In Jagdish Bhagwati, Pravin Krishna and Arvind Panagariya (eds.), The World Trade System: Trends and Challenges. Cambridge, MA: MIT Press.

Hoekman, Bernard. 2019. "Urgent and Important: Improving WTO Performance by Revisiting Working Practices," Journal of World Trade, 53(3): 373-94.

Hoekman, Bernard and Petros C. Mavroidis. 2015. "WTO à la Carte or WTO Menu du Jour: Assessing the Case for Plurilateral Agreements," European Journal of International Law, 26(2): 319-343.

Hoekman, Bernard and Petros C. Mavroidis. 2020. "Burning Down the House? The Appellate Body in the Centre of the WTO Crisis," EUI Working Paper RSCAS 2019/56.

Hoekman, Bernard and Douglas Nelson. 2020. "Subsidies, Spillovers and Multilateral Cooperation," in B. Hoekman and E. Zedillo (eds.), $21^{\text {st }}$ Century Trade Policy: Back to the Past? Brookings Institution, forthcoming.

Hoekman, Bernard and Charles Sabel. 2019. "Open Plurilateral Agreements, International Regulatory Cooperation and the WTO," Global Policy, https://doi.org/10.1111/1758-5899.12694.

Hofmann, Claudia, Alberto Osnago and Michele Ruta. 2019. "The Content of Preferential Trade Agreements," World Trade Review, 18: 365-398.

Horn, Henrik, Giovanni Maggi, and Robert W. Staiger. 2010. Trade Agreements as Endogenously Incomplete Contracts, American Economic Review, 100: 394-419.

Horn, Henrik, Petros C. Mavroidis, and Håkan Nordström. 2005. Is the Use of the WTO Dispute Settlement System Biased?, in P.C. Mavroidis and A. Sykes (eds.), The WTO and International Trade Law/Dispute Settlement, Cheltenham, UK: Edward Elgar.

Horn, Henrik, Petros C. Mavroidis, and André Sapir. 2010. Beyond the WTO? An Anatomy of the US and EU Preferential Trade Agreements, The World Economy, 33: 1565-1588.

Hudec, Robert E. 1980. GATT Dispute Settlement After the Tokyo Round: An Unfinished Business, Cornell International Law Journal, 13: 145-181.

Hudec, Robert E. 1988. Reforming GATT Adjudication Procedures: The Lessons of the DISC Case, Minnesota Law Review, 72: 1443-1481.

Hudec, Robert E. 1993. Enforcing International Trade Law, Butterworths: London, UK.

Hudec, Robert E. 2002a. Book Review: Free Trade, Sovereignty, Democracy: The Future of the World Trade Organization, World Trade Review, 1: 211-222.

Hudec, Robert E. 2002b. "The Adequacy of WTO Dispute Settlement Remedies for Developing Country Complainants," in B. Hoekman, A. Mattoo and P. English (eds.), Development, Trade and the WTO: A Handbook. (Washington DC: The World Bank).

Jackson, John H. 1978. The Jurisprudence of International Trade: the DISC Case in GATT, American Journal of International Law, 72: 747-781. 
Johannesson, Louise and Petros C. Mavroidis. 2015. Black Cat, White Cat: the Identity of the WTO Judges, Journal of World Trade, 49: 685-698.

Johannesson, Louise, and Petros C. Mavroidis. 2017. The WTO Dispute Settlement System 1995-2016: A Data Set and Its Descriptive Statistics, Journal of World Trade, 51(3): 357.

Limão, Nuno and Kamal Saggi. 2008. "Tariff retaliation versus financial compensation in the enforcement of international trade agreements," Journal of International Economics, 76(1):48-60.

Mattoo, Aaditya. 2018. "Services Globalization in an Age of Insecurity: Rethinking Trade Cooperation," World Bank Policy Research Paper 8579.

Mattoo, Aaditya, Nadia Rocha, and Michele Ruta. 2020. Handbook of Deep Trade Agreements. Washington, D.C.: World Bank, forthcoming.

McDougall, Robert. 2018. The Crisis in WTO Dispute Settlement: Fixing Birth Defects to Restore Balance, Journal of World Trade, 52(6): 867-896.

Mavroidis, Petros C. 2016a. The Regulation of International Trade, vols. I \& II. Cambridge MA: MIT Press.

Mavroidis, Petros C. 2016b. Dispute Settlement in the WTO: Mind over Matter, in K. Bagwell and R. Staiger (eds.), Handbook of Commercial Policy (Amsterdam: North-Holland.

Mavroidis, Petros C. 2020. The Regulation of International Trade, vol. III (The General Agreement on Trade in Services). Cambridge MA: MIT Press.

Mavroidis, Petros C., and Thomas J. Prusa. 2018. Die Another Day: Zeroing in on Targeted Dumping Did the AB Hit the Mark in US-Washing Machines? World Trade Review, 17: 239-264.

Mercurio, Brian. 2008. "Why compensation cannot replace trade retaliation in the WTO Dispute Settlement Understanding,” World Trade Review, 8(2): 315-38.

Nordström, Håkan. 2005. "The World Trade Organization Secretariat in a Changing World,”" Journal of World Trade 38 (5): 819-53.

Nordström, Håkan and Greg Shaffer. 2008. "Access to Justice in the WTO: The Case for a Small Claims Procedure,” World Trade Review, 7(4): 587-640.

Overdevest, C. and J. Zeitlin. 2018. "Experimentalism in Transnational Forest Governance: Implementing EU Forest Law Enforcement Governance and Trade (FLEGT) Voluntary Partnership Agreements in Indonesia and Ghana," Regulation \& Governance, 12(1): 64-87.

Pauwelyn, Joost. 2005. "Enforcement and countermeasures in the WTO: rules are rules-towards a more collective approach," American Journal of International Law 94: 335-47.

Pauwelyn, Joost. 2019. “WTO Dispute Settlement Post 2019: What to Expect?” Journal of International Economic Law, 22(3): 297-321.

Pauwelyn, Joost, and Krzysztof Pelc. 2019. "Who Writes the Rulings of the World Trade Organization? A Critical Assessment of the Role of the Secretariat in WTO Dispute Settlement," at: http://dx.doi.org/10.2139/ssrn.3458872.

Payosova, Tetyana, Gary Hufbauer and Jeffrey Schott. 2018. "The Dispute Settlement Crisis in the World Trade Organization: Causes and Cures." Washington D.C.: Peterson Institute for International Economics Policy Brief 18-5.

Petersmann, Ulrich. 2019. "How Should WTO Members React to Their WTO Crises?," World Trade Review, 18(3), 503-525. 
Schott, Jeffrey and Euijin Jung. 2019. "The WTO's Existential Crisis: How to Salvage Its Ability to Settle Trade Disputes," Washington D.C.: Peterson Institute for International Economics Policy Brief 19-19.

Stewart, Terence. 2019. "European Union Moves the Authorize Retaliation in Disputes Where There is No Alternative to the Appellate Body Pursued," at https://currentthoughtsontrade.com/2019/12/19/european-union-moves-to-authorize-retaliation-indisputes-where-there-is-no-alternative-to-the-appellate-body-pursued/

Sykes, Alan O. 2003. The Safeguards Mess: A Critique of the WTO Jurisprudence, World Trade Review, 2: 261-295.

Tijmes-Lhl, James. 2009. "Consensus and majority voting in the WTO," World Trade Review, 8: 41737.

Van den Bossche, Peter. 2006. "From Afterthought to Centerpiece, the WTO Appellate Body and its Rise to Prominence in the World Trading System," in Giorgio Sacerdoti, Alan Yanovich and Jan Bohannes (eds.), The WTO at Ten: The Contribution of the Dispute Settlement System, Cambridge: Cambridge University Press, pp. 289-312.

Wolfe, Robert. 2009. "The WTO Single Undertaking as Negotiating Technique and Constitutive Metaphor," Journal of International Economic Law 12(4), 835-58.

Wolfe, Robert. 2018. "Is WTO information good enough? How a systematic reflection by members on transparency could promote institutional learning," Background paper for the Bertelsmann project on the Future of Global Trade Governance

Wolfe, Robert. 2020a. "Improving the use of 'specific trade concerns' in WTO conflict management," Bertelsmann Stiftung, in process.

Wolfe, Robert. 2020b. "Informal learning and WTO renewal: Using thematic sessions to create more opportunities for dialogue," in process.

WTO. 2018. Communication from the European Union, China, Canada, India, Norway, New Zealand, Switzerland, Australia, Republic of Korea, Iceland, Singapore and Mexico to the General Council, WTO Doc. WT/GC/W/752 (26 November). https://trade.ec.europa.eu/doclib/docs/2018/november/tradoc_157514.pdf

WTO. 2019a. "Special Session of the Dispute Settlement Body: Report by the Chairman, Ambassador Coly Seck," TN/DS/31, June. Geneva: WTO.

WTO. 2019b. "Informal Process on Matters Related to the Functioning of the Appellate Body - Report by the Facilitator, H.E. Dr. David Walker," JOB/GC/222, 15 October.

Zhou, Weihuan and Henry Gao. 2019. "“Overreaching' or 'Overreacting'? Reflections on the Judicial Function and Approaches of WTO Appellate Body,” Journal of World Trade, 53(6): 951-978. 


\section{Author contacts:}

\section{Bernard M. Hoekman}

Robert Schuman Centre for Advanced Studies, European University Institute Villa Schifanoia, Via Boccaccio 121

I-50133 Florence

and CEPR

Email: Bernard.Hoekman@eui.eu

\section{Petros C. Mavroidis}

Columbia Law School

Edwin B. Parker Professor of Law at Columbia Law School

Jerome Greene Hall, Room 734

435 West 116th Street

New York, NY 10027

Email:pmavro@law.columbia.edu

and

Robert Schuman Centre for Advanced Studies, European University Institute Villa Schifanoia, Via Boccaccio 121

I-50133 Florence

Email: Petros.Mavroidis@eui.eu 